\title{
The Enlightened PRINCE SutAsOMA: TRANSFORMATIONS OF A BUDDHIST STORY
}

\author{
Angela Hobart
}

"Let us endeavor to perceive change as it is in its natural indivisibility; we see that it is then the very substance of things." 1

This study focuses on the Buddhist story of Prince Sutasoma and the Balinese experience of it. The prince, like Buddha who lived and taught around the fifth century BC in India, is the "Enlightened One," who emanates divine radiance and is distinguished by his wisdom, good will, and unlimited compassion for all living beings. The roots of the story go back to the Pali jatakas, yet it underwent various transformations in Java during the Hindu-Javanese period, and subsequently in Bali. Although the story engenders little interest nowadays in Java, it still enjoys considerable popularity in Bali, as both the nobility and the peasants find the prince a positive symbol who represents enlightened knowledge, benevolence, justice, and sweetness. These ideals continue to transmit energy which generates ever-new artistic creations, prime examples being dramatic performances, reliefs, and paintings. However, the story takes on different colorings and nuances depending on the intention of its creators or performers, the media used, and the beholders and interpreters. As such, it is continually adapted and modified to fit different contexts. It will even emerge that the symbols associated with the prince are concerned in a dialectical relationship with inherent contradictions prevalent in a society increasingly involved in the process of modernization.

After introducing the Sutasoma story and briefly tracing its development until it reached the literary form that still characterizes it in Java and Bali, I will turn exclusively to Bali where I did field work which contributed towards this article from 1979-1980 and

\footnotetext{
${ }^{1}$ H. Bergson, The Creative Mind: an Introduction to Metaphysics (New York: Citadel Press, 1965), p. 156.
} 
during a short visit in the summer of 1987.2 The discussion on Bali is divided into three parts. First, the story is placed in its historical and social setting. The second part concentrates on the performing arts, with specific reference to the shadow theater and contemporary drama. Special attention is given to the shadow theater, as this is the main vehicle through which most ordinary Balinese become acquainted with the subtleties of Prince Sutasoma's teachings. The spectators' experience of a specific shadowplay performance of the Sutasoma story is discussed in this context. Contemporary drama is of interest as it presents issues relating to the modernizing world. Here, in a relatively progressive setting, Sutasoma may appear as a minor character or he may be alluded to in the course of a play. Finally, paintings and reliefs of the story are examined with a view to understanding their varying significance to the aristocrats and the commoners, the Sudras.

\section{Background}

The story of Prince Sutasoma is preserved in two Old Javanese texts, Mpu Tantular's kakawin, poem, of the fourteenth century and the Cantakaparwa, which contains an abridged version of the poem, compiled in the fifteenth or sixteenth century. ${ }^{3}$ It is the former text which mainly concerns us here, as it is the one to which all my Balinese informants referred. Mpu Tantular's poem is unique among the epic kakawin literature of the Hindu Javanese period in being Mahayana Buddhist in orientation. ${ }^{4}$ Its special appeal, however, particularly in Bali still today, relies on its profound metaphysical speculations and didactic potential.

The story of Sutasoma, ${ }^{5}$ an incarnation of Buddha, is found in more than twenty Indian texts. These were comprehensively studied by Kaigvoko Watanaba, ${ }^{6}$ and on the

\footnotetext{
${ }^{2}$ In this article I want to acknowledge the help of the dalang I Ewer, the painter Nyoman Mandera, and I Ketut Kacir who assisted me in recording and transcribing I Ewer's performance of the Sutasoma story.

Outside of Bali I want to express my special thanks to Ruth McVey for her comments on the article. I am also grateful to Dr. Skorupski from the School of Oriental and African Studies and Toru Aoyama. The former drew my attention to the Suvarnabhāsottamasütra text and the latter in a written communication in 1987, gave me detailed information on the historical background of Mpu Tantular's Sutasoma kakawin.

The spelling of Balinese in the paper follows the official Indonesian system introduced in 1972. ' $\mathrm{E}$ ' and 'è' are distinguished as in French from ' $e$,' the central vowel. Titles of texts, however, are written with diacritics according to the conventional Sanskrit or Old Javanese orthographies.

${ }^{3}$ The Cantakaparwa does not differ substantially from Mpu Tantular's kakawin and was clearly influenced by it. According to J. Ensink, On the Old Javanese Cantakaparwa and its Tale of Sutasoma, Verhandelingen van het Koninklijk Instituut voor Taal-, Land- en Volkenkunde, vol. 54 (The Hague: Nijhoff, 1967), p. 11, the main differences are as follows: the former gives more genealogical details, minor incidents are changed, and many persons have different names. Toru Aoyama (in a written communication to me in 1987) pointed out three additional changes: the Cantakaparwa is structured so that it follows a more defined chronological sequence of events, original theological teachings are replaced by down-to-earth preachings, and Middle Javanese speech is employed for personal names.

${ }^{4}$ P. Zoetmulder, Kalangwan: a Survey of Old Javanese Literature (The Hague: Nijhoff, 1974), p. 346.

${ }^{5}$ The Pali jataka No. 537 also gives an explanation of the name Sutasoma (suta in Sanskrit means child and soma refers to the soma plant). The enlightened prince is so called because of his fondness for the potent pressed juice derived from the Vedic soma plant. E. B. Cowell, The Jataka or Stories of the Buddha's Former Births, vol. 5 (Cambridge: Cambridge University Press, 1905), p. 246.

The sap of the soma plant had strong intoxicating or more probably hallucinogenic properties. In the $R g$ Veda (III, 48, 2) soma is said to be of divine origin. Soma juice was the essential libation of all early Vedic sacrifices. While ostensibly an offering to the gods, it was a desirable drink for the participating priests. M. \& J.
} 
basis of this work, the scholar Toru Aoyama7 argues that Mpu Tantular's poem originates from the Pali jataka No. 537, one of the jatakas incorporated in Ceylon in the fifth century AD in the "Third Basket," Sutta Pitaka, of the Pali canon of the Theravada school. The jatakas are vivid folk tales, adapted to Buddhist purposes, and ascribed to the Buddha, who is said to have told them as recollections of his previous births as a bodhisattwa, a being destined to reach Buddhahood.

However, although the Sutasoma kakawin is a Buddhist story, the structure of the Old Javanese poem departs radically from the Pali version. As Toru Aoyama points out, Mpu Tantular essentially created a new story, using only the skeleton of jataka No. 537 into which he inserted motifs from Buddhist texts and Hindu epics. ${ }^{8}$ The scholar further suggests that the core of Mpu Tantular's poem is Sutasoma's pacification of the Maneater, called Kalmasapada in some Indian Buddhist texts, notably the fourth century Jätakamālā, and Porusada in Java. ${ }^{9}$

Toru Aoyama does not draw special attention to the incident in Mpu Tantular's poem when the prince encounters a hungry tigress. But this scene is frequently portrayed in Balinese expressive genres (for example, in the Balinese shadow theater where this encounter is colorfully narrated). While it is not elaborated on in the Pali jatakas, it occurs in Mahayana texts where, in a manner reminiscent of St. Francis of Assisi, the bodhisattwa extends good will to numerous animals, with particular reference to a tigress. ${ }^{10}$ The oldest of these texts is the Sanskrit manuscript Suvarnabh āsottamas ūtra, completed at the beginning of the fifth century, 11 which was translated into Tibetan, Chinese, Hsi-hsia (Tangut), Uighur, Mongol, Sogdian, and Shotanese. It was also known in Japan in the seventh century.

It is worth noting that the scene of a prince with a hungry tigress is depicted on a relief of the magnificient ninth century monument Borobudur. ${ }^{12}$ Other panels of reliefs on the balustrades of the monument present visual evidence of the jatakas, as well as the Sutasoma story. Toru Aoyama suggests that these latter reliefs are based on the Sanskrit Jātakamālā. ${ }^{13}$

Mpu Tantular, who belonged to the priestly elite and who may have been a Buddhist, composed the Sutasoma kakawin during the reign of king Rajasanagara (Hayam Wuruk) at the height of the Majapahit era. The poem is clearly a distinct product of the East Javanese period which is marked by the growing syncretism of Buddhist and

Stutley, A Dictionary of Hinduism: its Mythology, Folklore and Development 1500 B.C. - A.D. 1500 (London: Routledge \& Kegan Paul, 1977), p. 282.

${ }^{6} \mathrm{~K}$. Watanabe, "The Story of Kalmāsapāda and its Evolution in Indian Literature," Journal of the Pali Text Society (1909): 236-310.

${ }^{7}$ Toru Aoyama, "The Adoption and Structural Transformation in Old Javanese Literature of Sutasoma, an Indian Buddhist Story," Tonan Ajia Kenkyu (Southeast Asian Studies) [Kyoto] 24, 1 (1986): 3-17.

8 ibid., p. 3.

${ }^{9}$ Through his analysis of the origin of Mpu Tantular's kakawin, Toru Aoyama further refutes Kern's contention that the kakawin is modeled on an unknown north Buddhist text in Sanskrit. H. Kern, "Kalmasapada en Sutasoma," Verspreide Geschriften 3 (The Hague: Nijhoff, 1915): 123-51.

${ }^{10}$ Leon Feer,"Le Bodhisattva et la Famille de Tigres," Journal Asiatique 14 (1899): 272-79.

${ }^{11}$ R. E. Emmerick, The Sutra of Golden Light: Being a Translation of the Suvarnabhasottamasutra (London: Luzac, 1970), pp. 85-97.

12 A. J. Bernet Kempers, Ageless Borobudur (Wassenaar: Servire, 1976), p. 127.

${ }^{13}$ Aoyama, "The Adoption and Structural Transformation in Old Javanese Literature of Sutasoma." 
Siwaite cults, tinged with Tanric elements. Prince Sutasoma in the poem is not a bodhisattwa, although he may be called one. He is Buddha himself. During the course of the poem he is given a variety of names, such as Wairocana (Lord of Supreme Buddhas, Jinas), Buddha (implying Paramabuddha, the Absolute Buddha, the perfect Void), Sakyamuni, or Gotama. 14

The syncretic tendency of the poem may in fact mirror Rajasanagara's own status, for he was said to be an incarnation of Siwa-Buddha. ${ }^{15}$ Soewito Santoso ${ }^{16}$ also argues that the Old Javanese Sutasoma reflects the process of Siwa-Buddhism being absorbed into "guruism," i.e., a more indigenous conception of Siwaism and Mahayana Buddhism merging into a two-in-one deity. ${ }^{17}$ The complementary opposition alluded to here also emerges when we examine Sutasoma's teaching in the shadow theater.

It is relevant at this stage to give a brief outline of Mpu Tantular's poem, ${ }^{18}$ with special attention to those people or scenes that are depicted in Balinese artistic works. In the story Sutasoma is the son of King Mahaketu, of Kuru descent, who rules over Nastina. To his parents' dismay, the prince quietly one night leaves the palace to meditate on Mount Meru. At the foothill of the mountains he enters a cemetery to worship Durga. The goddess appears to him and teaches him a mantra (ritual incantation) which enables him to dispel all harmful forces in the world. Sutasoma then continues on his way. Soon he meets the Siwaite priest Kesawa and the Buddhist priest Sumitra, and both join him in his travels. On entering deeper into the woods, he encounters three wild creatures, an elephant-headed giant, a serpent, and a tigress, whom he subdues and who become his faithful pupils. The prince teaches them the path that leads to absolute purity and inconceivable emptiness (acintyasunya). He further explains that good will should be extended to all beings, even if this involves death. The prince also indicates that the Buddhist practice, the yoga of non-duality (adwayayoga), is superior to the Siwaite yoga. It is essential, however, to know both paths for both lead to liberation. He then tells each of his pupils to go off to meditate alone. He does likewise. Some time after this Sutasoma marries Candrawati, who had been his consort in the heaven of Supreme Buddhas. Later fierce fighting breaks out between Sutasoma's cousin Dasbahu and his allies and the demon-king Porusada ("Man-eater") who has vowed to sacrifice one hundred kings. Finally, through his compassion and wisdom, Sutasoma pacifies Porusada and Kala, the destructive manifestation of Siwa. It is of interest that the gods at this stage descend to help appease Kala, who is about to destroy the world, by pointing

${ }^{14}$ Zoetmulder, Kalangwan, pp. 329-41.

${ }^{15} \mathrm{Mpu}$ Tantular at the end of the kakawin mentions the king's name, and praises him, while expressing the hope that the kakawin will contribute to harmony in the realm and the well-being of the dynastic family, one of whose members is his patron. Ibid., p. 342.

According to Schrieke some literary works were thought to augment the mystic light of the king who was considered god incarnate, and it can be suggested that the idealizations inherent in the kakawin helped to affirm and legitimize the power that king Rajasanagara celebrated. B. Schrieke, Ruler and Realm in Early Java (The Hague: Van Hoeve, 1957), pp. $83 \mathrm{ff}$.

${ }^{16}$ Soewito Santoso, Sutasoma: A Study in Javanese Wajrayana (New Delhi: International Academy of Indian Culture, 1975), pp. 126-27.

${ }^{17}$ Toru Aoyama, who is presently working on the religious aspects of Mpu Tantular's Sutasoma kakawin, further tantalizingly suggests (in his communication of 1987) that this duality has taken on a new meaning by acquiring a nationalistic flavor as, for example, evidenced in the red-and-white national flag.

${ }^{18}$ For a fuller summary, see Zoetmulder, Kalangwan, pp. 329-41; also the philosophical treatise by Soewito Santoso on the boddhakâzya Sutasoma; see above n. 16. 
out to him that "Buddha and Siwa are one in their deepest essence."19 Siwa then reascends to heaven where he rules again as Pasupati, Lord of all creatures.

I now want to turn to Bali for here the story of Sutasoma continues to be perpetuated in varied expressive genres and retains significance for the people.

\section{Bali}

\section{Historical and Social Setting}

Traces of Buddhism in Bali date back to the ninth century AD, perhaps introduced directly from India via monks and priests. ${ }^{20}$ Yet Buddhism has left little overt imprint on the religious life of the common people, the Sudras, who make up over 90 percent of the population. They revere a pantheon of gods, among which is the Hindu TrinityBrahma, Wisnu, and Siwa-and the ancestors. In fact the religion is best called agama tirta, as purification by holy water is so important in all rituals. ${ }^{21}$ Nonetheless, it is worth noting that there are still today two kinds of Brahman priests, who are the spiritual apex of a society stratified into ranked descent groups based on an ideology similar to the Indian caste system. Brahman priests, however, form a very small percentage of the population. Hooykaas has pointed out that there are fewer than a score of Buddhist priests and perhaps ten times as many Siwaite priests. ${ }^{22}$ While the distinction between them is essentially nominal, it is of interest that Buddhist traditions seem to be kept alive among the former priests. During his consecration ceremony a new Buddhist priest (resi-yadnya) must symbolically undergo his own funeral in order to be reborn as an elevated spiritual person, a padanda Boda. ${ }^{23}$

The ultimate sources of knowledge on religious matters, particularly for the Brahman priests, are the palm-leaf manuscripts. Bali is, of course, renowned for its vast and rich literary culture. From the eleventh century onwards, literary works filtered into the island from Java. But such poems as Sutasoma would have reached Bali only after the Majapahit expedition in 1342 when the island became a dependency of the great empire. It can be surmised that, with the triumph of Islam in Java in the fifteenth century and the decline of the Majapahit era, the Hindu-Javanese tradition waned in importance there. It continued to be preserved at the Balinese courts, however, especially in the socalled heartland, the south central part of the island. Here Old Javanese texts, among which Sutasoma must have featured, were avidly studied, translated, and amplified.

In order to understand the significance of the ancient texts over the years, it is relevant to draw attention to the manner in which they are read and used. Throughout Bali there exist study groups or clubs, sekaha babasan, which comprise about ten male members who meet regularly about once a week or for festive occasions. The clubs are usually linked to courts in bigger villages or towns. (Nowadays there are a few such clubs for women.) Mabasan or papaosan, as it is also called, is a literary event which entails the alternation between one man chanting the written text, and another translating, para-

\footnotetext{
${ }^{19}$ Zoetmulder, Kalangwan, p. 341.

${ }^{20}$ W. E. Stutterheim, Indian Influences in Old Balinese Art (London: Indian Society, 1935), p. 10.

${ }^{21}$ C. Hooykaas, The Religion of Bali (Leiden: Brill, 1973), p. 11.

${ }^{22}$ C. Hooykaas, Balinese Bauddha Brahmans, Verhandelingen der Koninklijke Nederlandse Akademie van Wetenschappen 77 (Amsterdam: North-Holland, 1973), p. 8.

${ }^{23} \mathrm{~J} . S$. Lansing "Balinese Religion" in The Encyclopedia of Religion, vol. 2, ed. M. Eliade (London: Macmillan, 1987), pp. 48-49.
} 
phrasing, and commenting on it in Balinese. The other members of the group listen and contemplate the meaning of the text. ${ }^{24}$

Although members of these clubs tend to be drawn from all castes, they are scholarly inclined, and often include dalang, poet-priests, artists, and skilled craftsmen. By participating in these literary events, they can gain deep knowledge of the Classics. It is worth noting here that, according to Ensink, Mpu Tantular's kakawin Sutasoma is one of the five most highly regarded poems among Balinese literati, the other four being the Rām āyana, Bh ăratayuddha, Arjunawiwäha, and Bhomakāwya. ${ }^{25}$ Hence, marked preference is shown for these works in study clubs. ${ }^{26}$ The special value of Sutasoma is thought to be its profoundness and message of asceticism and meditation.

Balinese can also become acquainted with Prince Sutasoma and other epic heroes from a number of other literary sources. These include parikan, poems, in Indonesian metres and in simple modern Balinese language, ${ }^{27}$ modern books, and cassettes. A cassette of Mpu Tantular's kakawin Sutasoma, for example, is easily obtainable in shops these days.

However, most villagers gain knowledge of the classical literature through the performing and pictorial arts. Here the literary tradition is continually recreated and reinterpreted. This applies especially to the shadow theater, the main vehicle for disseminating the epic literature and such stories as Sutasoma. As will emerge in the subsequent discussion, it is primarily on the stage that outside influences are ever anew entwined with indigenous Balinese traditions. In fact, as Hildred Geertz has stressed, "to be 'traditional' does not mean to be inflexible," 28 innovations are continually adopted, but within traditional channels. The ease with which the new is blended with the old, moreover, ensures the viability of the arts where continuity is promoted by elasticity.

\section{The Performing Arts}

\section{The Shadow Theater}

The shadow theater is the most revered and conservative art form in Bali, as well as being the most ubiquitous, being performed in the most isolated of hamlets. Unlike Java no efforts have been made to revise and secularize the performance in line with ideological changes. ${ }^{29}$ All the elements of Balinese wayang (dramatic performance or puppet) are imbued with symbolic import. Its sanctity helps account for the impact of this theater genre in the community.

\footnotetext{
${ }^{24}$ See S. O. Robson "The Kawi Classics" Bijdragen tot de Taal-, Land-en Volkenkunde, 128 (1972): 308-26; M. S. Zurbuchen, The Language of Balinese Shadow Theatre (Princeton: Princeton University Press, 1987), pp. 8795.

25J. Ensink "Sutasoma's Teaching to Gajavaktra, the Snake and the Tigress," Bijdragen tot de Taal-, Land-en Volkenkunde, 130 (1974): 195.

${ }^{26}$ Cf. Zoetmulder Kalangwan, p. 50.

${ }^{27}$ Ensink, On the Old Javanese Cantakaparwa, p. 11.

${ }^{28} \mathrm{H}$. Geertz, Indonesian Cultures and Communities: Study Guide (New Haven: HRAF Press, 1963), p. 38.

${ }^{29} \mathrm{R}$. McVey, "The Wayang Controversy in Indonesian Communism," in Context, Meaning and Power in Southeast Asia, ed. M. Hobart and R. H. Taylor (Ithaca: Cornell University Southeast Asia Program, 1986), pp. 38-41; V. M. C. van Groenendael The Dalang Behind the Wayang: the Role of the Surakarta and the Yogyakarta Dalang in Indonesian-Javanese Society, Verhandelingen van het Koninklijk Instituut voor Taal-, Landen Volkenkunde, 114 (Dordrecht: Foris Publications, 1985), pp. 196-203.
} 
The dalang is a poet-priest who has to be consecrated before he is allowed to perform. During the show he is said to be inspired by the gods so that he can reveal the sacred truths embedded in the Classics. Ideally dalang should be triwangsa, of high caste, literary and religious matters being their perogative. Yet most are Sudras. Generally the craft of wayang passes down the patriline and most dalang learn from the elder generation or by observing performances, also of other dramatic genres.

As the training they receive is so unsystematic, the dalang vary greatly in the level of scholarship they attain. The skeleton of the plot, however, is always drawn from the classical literature. In the context of this article, the most important cycle of myths is what is known as wayang parwa. While most plays are based on the great Hindu epic the Mahābhärafa, Sutasoma also belongs to the cycle. Learned Balinese consider the text's inclusion justifiable, as Prince Sutasoma is a direct descendant of Arjuna from the epic, in the fourth generation.

Yet the dalang on the stage improvises considerably, interspersing the main plot with spicy episodes which reflect the daily life of the people. Here the Sudra servants play a crucial role. The four principal ones are Tualèn (the equivalent of Semar in Java), his son, Merdah, and the brothers Dèlem and Sangut. Although they belong to the folk tradition and do not appear in the Hindu epics, or such stories as Sutasoma, they are in many ways the most important characters in any performance. It is they above all who interpret the classical literature. The other characters on the stage speak the archaic language of Old Javanese which is inaccessible to the predominantly Sudra audience who speak Balinese. The servants translate and often elaborate extensively on what the others say. It can be suggested that, in doing so, they create the requisite open space where issues can be explored and questioned. ${ }^{30}$

Apart from the servants, there are three other main groups of characters, or puppets, drawn for the most part from the Classics: the celestial beings, high castes, and ogres. These figures all have standard characteristics which are not unique to one individual; rather each is built up from a limited number of possibilities determined by strict conventions. The most important parts are the headdress or hairstyle and facial features which carry meanings shared to a remarkable degree across the island. They immediately indicate to the spectators a character's social status and type, whether refined or coarse and uncivilized. Sutasoma's appearance (Plate 1) highlights the degree to which he has been integrated into the wayang tradition. Like other eminent Satriya, he wears the elegant supit urang headdress, with two upward sweeping curves, indicative of his princely status and uprightness, and has elongated eyes, which mirror his refined nature.

Sutasoma's dance and voice on the stage underlie the nobility of his appearance. He speaks to all in a gentle, soft voice, with "sweet" (manis) eloquence, and he dances with grace. In contrast, ogres and creatures, who stand out by their rough looks, speak in base voices and dance with gaucheness.

There are two types of wayang performances in Bali: wayang peteng, the night performance given with a screen, and wayang lemah, the day performance without a screen. The night wayang sets out to communicate to spectators. The day wayang, on the

${ }^{30}$ Cf. B. A. Babcock, "Arrange Me into Disorder: Fragments and Reflections on Ritual Clowning" in Rite, Drama, Festival, Spectacle, ed. J. MacAloon (Philadelphia: Institute for the Study of Human Issues, 1984), p. 104. 


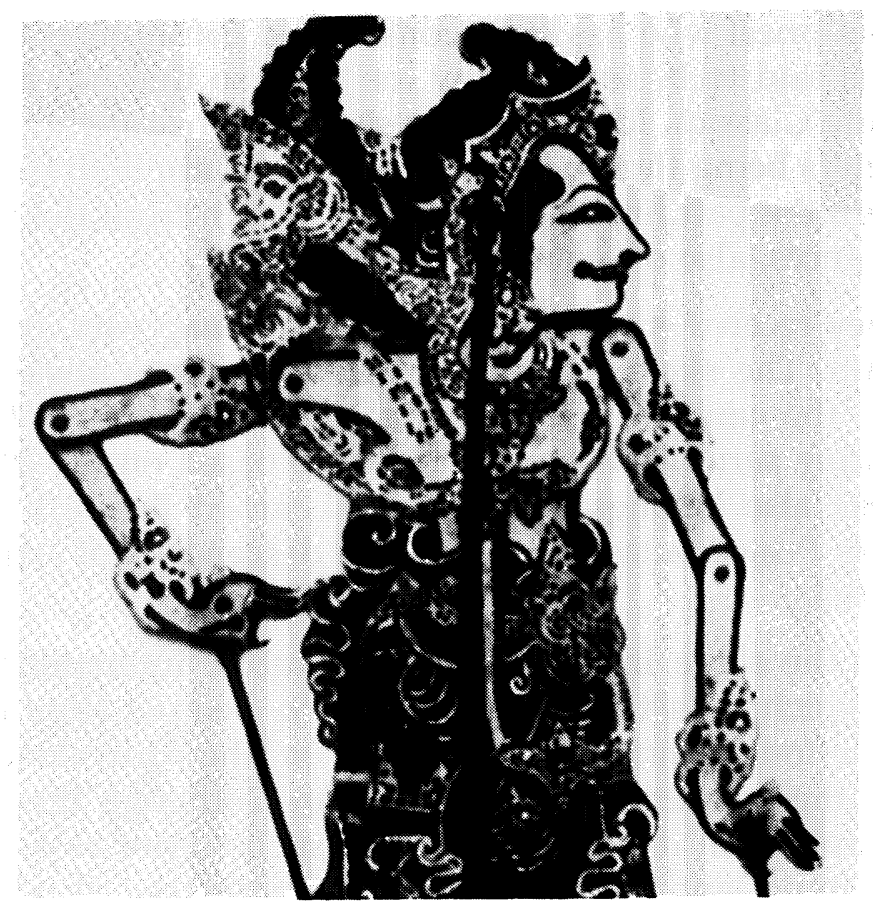

Plate 1. Puppet of Sutasoma

other hand, is a simple show which is essentially a rite presented to the gods. ${ }^{31}$ The Sutasoma story may be narrated in both types of wayang.

The main occasion for the performance of a night wayang is in conjunction with the anniversary of a temple (odalan), which takes place every 210 days, when it is paid for by the temple congregation. It is then usually the dalang who chooses which story to narrate. However, if a night wayang is performed in a household as, for example, during a rite of passage, the sponsor may select the story. While myths telling of the five Pandawa brothers from the Mahäbhärata are particularly popular, the story of the noble Prince Sutasoma is also beloved and hence may be chosen by either the dalang or sponsor. ${ }^{32} \mathrm{~A}$ Sutasoma story dramatized at night, like all night wayang, must involve conflict between two sides, even though the prince, for reasons that will emerge, never actively participates in the fray.

On the other hand, dalang interviewed pointed out that "Durga's gift to Sutasoma" (Sang Sutasoma keicèn penugrahan antuk Ida batara ring Dalem) is suitable for a day wayang, especially if it is given in the pura dalem, death temple, on the occasion of its anniversary, as the temple is dedicated to Durga. The goddess in Bali is associated with mystic power, which in a dramatized story she grants Sutasoma in the form of a mantra which he uses for the purpose of good (see summary of Mpu Tantular's kakawin).

${ }^{31}$ Wayang lemah lasts only one to two hours. It takes place on the ground in a sacred zone in a temple or household. The stories, which are hardly audible to the few humans nearby, always accord with the overt purpose of the ceremony. As this type of theater does not communicate to spectators, I am not dealing with it in this article.

${ }^{32}$ See Ensink, On the Old Javanese Cantakaparwa, p. 3, who confirms this. 
At this point I would like to turn to an actual night wayang based on the Sutasoma story, as in it the prince's compassionate and enlightened nature comes to the fore. These qualities enable him to act as a moderating and civilizing force which is central to the Balinese appreciation of him.

This particular performance took place in 1980. It was given by dalang I Ewer, who is elderly, of low caste, and highly respected for his literary knowledge acquired in his youth through his participation in the study clubs, mentioned earlier. He derived the story from the kakawin Sutasoma composed by Mpu Tantular. Although I Ewer knows the Cantakaparwa, he explained that he always used the kakawin for wayang, as, being older, it is more authentic, and is replete with philosophical and religious content. Other dalang concurred with I Ewer's view.

As I Ewer's voice does not carry far, he performed the play in a pavilion in his home near Ubud, in Gianyar. The performance was given as edification and entertainment for an audience consisting, as is usual for night performances, largely of men and some boys. The play began with the figure, the Kakayonan, the Tree of Life or sacred "Center of the World" (Plate 2), appearing on the stage. The figure opens up communication between cosmic realms-heaven, earth, and underworld. ${ }^{33}$ All night wayang commence this way. Only then did I Ewer start to narrate.

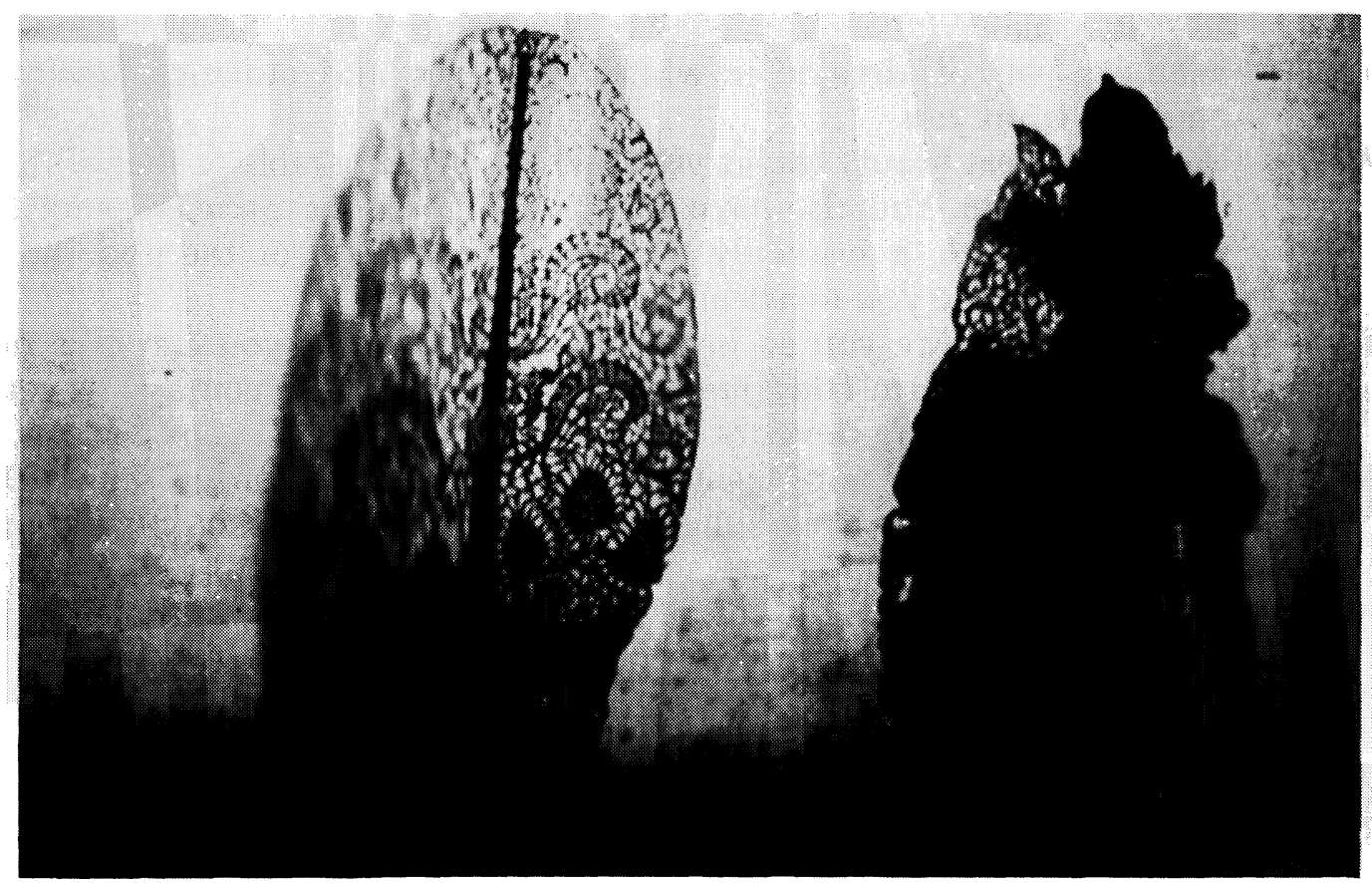

Plate 2. Silhouette of the Kakayonan, the Tree of Life, and an ogre. (1980)

${ }^{33} \mathrm{M}$. Eliade, The Sacred and the Profane: the Nature of Religion (New York: Harcourt Brace Jovanovich, 1959), p. 37. 


\section{Prince Sutasoma goes to the woods (Sang Sutasoma lunga lunga ka alase)}

Introduction. The dalang explains that ogres have brought chaos to the world. Thus Prince Sutasoma, called Batara Budha, Lord Buddha, is born to bring back order and peace through his wisdom and right conduct. To the consternation of his parents, however, he does not wish to rule, and one night he quietly leaves the palace to practice ascetism (tapa) and to meditate (yoga) on Mount Meru. The play proper then unfolds.

Episode 1. Sutasoma and his servants, Tualèn and Merdah, are on their way to the mountains. The servants frolic around and joke. In due course sages join them including the Buddhist priest Sumitra and Siwaite priest Kesawa. They warn Sutasoma of the dangers in the woods, where ogres lurk behind trees. A number of skirmishes break out between the ogres and Sutasoma's followers. Finally, they reach an open space of ravaged ground. The following discussion ensues between Sutasoma, his servants Tualèn and Merdah, and later with the elephant-headed giant, called here Gaja Waktra, ${ }^{34}$ and his servant Dèlem. Sutasoma and Gaja Waktra talk in Old Javanese and the servants translate and comment in Balinese. As the dialogues are highly idiomatic and repetitive they are paraphrased throughout.

Merdah Father, father, look at the piled-up mounds of bones!

Sutasoma There are also heads on the ground and hair is strewn around.

Merdah These are the heads of kings tossed on the ground as if they were rocks, and their hair and clothing is scattered about.

Tualèn Gaja Waktra has caused this havoc. He has devoured all these men.

Gaja Waktra (to Sutasoma) Who are you, dressed like a sage (resi)?

Dèlem Who are you, all dressed in white? Authority and radiance, kawibawan, emanate from you.

Gaja Waktra You have great beauty (bagus pisan) which is comparable to that of the god of love, Semara. You also have the sign of the discus, cakra, on your hand. Are you a sage, a heavenly musician (gendarwa) or the god Indra or Wisnu? If so, are you mystically powerful, sakti?

Dèlem Who are you? Are you so mystically powerful that you can take on the transcendental form triwikrama? ${ }^{35}$ No person has the courage to venture here as Gaja Waktra devours all men.

Sutasoma I am neither Indra nor Wisnu. I am a human, the son of King Ketu of Nasina. My name is Sang Sutasoma and I wish to prevent you from causing more devastation.

Tualèn He is Sang Sutasoma, the son of King Ketu of Nastina, on the way to the mountains. He follows the path of darma, virtue and duty, and wishes to instruct you so that you desist in your path of greed (ngemargiyang kemomoan). Like one who is continually drunk (on local spirits, arrak, and palm wine), you are indulging in lustful desires. Your behavior is like that of an animal (laksana sekadi beburon) and hence you have an elephant's head. Sutasoma feels compassion (kepiolasan) and pity (kangen) for all that lives. If you continue in your evil ways you will suffer sangsara in the hereafter and not attain final liberation (moksa).

\footnotetext{
${ }^{34}$ Gaja Waktra in Mpu Tantular's kakawin is called Durmuka or Gajamuka. Zoetmulder, Kalangwan, p. 332.

${ }^{35}$ Kresna is the most well-known Satriya to take on the form of triwikrama. He does so before the Great War when he becomes angry with the Korawa for not heeding their advice. Ibid., p. 267.
} 
Gaja Waktra You are proud and talk too much! I do not believe you are of royal descent. It is not for you to admonish me.

Gaja Waktra then takes on the terrifying form of triwikrama. But Sutasoma, from the power of his thoughts, creates the weapon Bidura which strikes the giant so that he becomes immobile. Ganésa then enters Gaja Waktra, who realizes that his path is evil. He pays homage to Sutasoma and asks to become his pupil. Ganésa ascends back to heaven.

Episode 2. Sutasoma and the sages continue on their path. Suddenly a cruel, wild (galak) snake attacks Sutasoma. Gaja Waktra, enraged, wishes to kill the snake, but the prince deters him. from this by saying that, in order to be pure in thought (pikayune nirmala), one must learn to have compassion for all beings and destroy no form of life. In awe at seeing Gaja Waktra's fury abate, the snake pays homage to him and his master and asks the latter if he too can become his pupil.

Episode 3. Soon afterwards they encounter a tigress who is about to devour her cubs. Sutasoma admonishes the tigress to desist from this wicked deed, and the following discussion takes place between the prince, his servants, and the tigress.

Merdah The tigress wishes to devour her cubs, who are too weak to flee and are crying in fright.

Sutasoma Stop, stop, tigress! What are you doing?

Merdah Mother tigress, do not devour your cubs. This is the evilest (kelintang kaon) of deeds.

Sutasoma Mother tigress, desist from this wicked act. Remember you brought them into the world. You are committing two evil deeds in one, for you are neglecting your two roles: to be their parent ( $i$ rerama) and spiritual teacher (guru nabé). Consider the consequences (pikolih). You will have to suffer one thousand years in hell.

Merdah (expanding on Sutasoma's words) You are setting your cubs a poor example. Later they too will become bad parents, and cruel and greedy. They will also not treat you well when elderly.

Tualèn Yes, mother tigress listen to Sang Sutasoma. It is important that you understand the meaning of darma.

Tigress I wish to devour my children as I am hungry. All the animals-the monkeys and wild pigs-have fled and hence there is nothing to eat.

Tualèn In her hunger, mother tigress has forgotten these are her children. She no longer knows her limitations.

Sutasoma, in compassion, then offers his body to the tigress as food. He dies as she claws his chest and imbibes his blood. But this acts like (a)merta, the elixir of immortality, and she becomes aware of her wickedness. In misery, she tries to kill herself, but Indra descends and prevents this. The god also brings Sutasoma back to life, for he is required in the world in order to bring order and prosperity to the land. The tigress then worships the prince and asks to become his pupil. The prince points out that "it is appropriate in the context of Balinese religion to pay homage to Lord Buddha" (nunas ica ring Sang Hyang Buda nganutin sekadi kekecap Sang Hyang Agama).

Episode 4. The three pupils then request their master to teach them so that they develop spiritually. In these erudite speeches Merdah and Tualèn expound on Sutasoma's teachings. 
Merdah (to the pupils) Children, realize that all matter consists (in varying degrees) of the triad, triguna (the qualities of purity, passion, and ignorance). All manifestations of life can further be arranged into dichotomies, ruwabinèda (the complementary opposites). In order to attain final liberation you must transcend this level and realize a state of non-duality (ngicalang sané kekalih). While on earth you must also become aware of the triad, actions (bayu), speech (sabda), and thought (idep). These three must be united. Only then will you act according to the traditional customs in the community (susila), speak in a "sweet" manner to all, and possess pure and noble thoughts. You should also not seek earthly wealth. Once your thoughts are pure you will develop compassion for all living beings, helping those in distress, even if his entails giving up your life for them.

Tualèn Listen to Sutasoma's teachings. When you are no longer impure (leteh), you will be happy and compassionate to all beings.

Sutasoma In order to proceed, your thoughts must be concentrated and have a direction.

Tualèn My children, Gaja Waktra, serpent, and mother tigress, once you obtain "single-mindedness" (nyikiyang pikayun) nothing can disturb you. This is the path of Buddhahood (ngemargiyang kebodan).

Sutasoma further explains that there is essentially no difference between the scriptures (tutur) of the Buddhist and Siwaite priest. It is important to know both for spiritual progress. The prince then tells his three pupils each to go off and meditate alone. He does the same. The priests Kesawa and Sumitra and the sages return to their hermitage.

Episode 5. In fear that the demon-king Porusada will now destroy the world, the gods decide to disrupt Sutasoma's meditation. Beautiful celestial nymphs are sent down to seduce him, but without avail. So Sutasoma demonstrates the steadfastness of his meditation.

In order to understand the Balinese experience of the above Sutasoma story, it is relevant to draw attention to the instructive value of the plays which articulate popular ideals and proper behavior to the populace. In fact Balinese of all castes point out that the shadow theater is one of the main didactic and religious vehicles on the island. In line with this the dalang is a recognized teacher in the community, albeit an informal one. It is further striking that the most eloquent speeches in all-night performances are made by the Sudra servants, who represent the village sphere and with whom most of the spectators can identify. It is the servants who expound on ethical values and cosmological ideas which reflect ontological understandings. These, however, are contextualized so that they are explained in familiar terms to the villagers. At the same time, the servants, through their deferential behavior and speech, uphold the status of those in higher positions than themselves. It is in this light that the vitality and profundity of Prince Sutasoma's message in this particular performance emerges.

Sutasoma in the play given by I Ewer, in a sense, epitomizes civilized man who tames the wilderness or, in Balinese words, "brings light where there is darkness" (galang peteng). This he achieves by imparting knowledge to those who are still unenlightened or ignorant, here represented by Gaja Waktra, the serpent, and the tigress. Initially this view seems to accord with a structuralist interpretation, where primacy is placed on the intellect. For Lévi-Strauss, man progresses from animality to humanity, 
from nature to culture, from affectivity to intellectuality. ${ }^{36}$ However, a structuralist approach gives short shrift to beliefs and emotions, assumptions and desires, i.e., the innuendoes in the values portrayed in the play which are intrinsic to the Balinese world.

Already the triads referred to in Merdah's speech (see performance, Episode 4) fit ill with such Western dichotomies and highlight the ontological status of Sutasoma's teachings. The triad triguna (which is adapted from a Hindu model) comprises the qualities of sattwa (knowledge and purity), raja (passions and feelings), and tamas, (desires and ignorance). This triad is closely linked to the forces manifest in various degrees in all beings: idep (thought), sabda (voice), and bayu (energy or action). ${ }^{37}$ These two triads account for all that exists in the world. The lowest ranking are plants and objects which just possess energy and are ignorant. Further up the ladder are animals who have speech and energy, but no thought. Only gods and humans are endowed with thought, speech, and energy; concomitantly they can become knowledgeable and pure. To most Balinese the position of ogres, the category to which the elephant-headed giant, Gaja Waktra, is said to belong, is somewhat unclear. Ogres are said to have once existed on the island, living deep in the forest. Above all, to the villagers they represent the wild which threatens human settlement, and they are feared and held in awe. This is especially so as they can think yet they indulge in lustful desires. As Sutasoma elucidates to Gaja Waktra (in Episode 1), he is following the path of greed and acting like one who is drunk, i.e., showing no awareness of his limitations. As a result, he will suffer terribly in the hereafter. It is interesting that evil here denotes an area of discourse concerned with depradation and suffering which the prince in this story tries to resolve. ${ }^{38}$ Animals, such as the serpent and tigress, are too base to offer humans the same degree of danger. However, as Sutasoma points out, they too can experience pain and suffering.

But change is intrinsic to the world order. All forms of life are born, die, and are reincarnated in line with the laws of cause and effect, karma (or karmapala). A human who is crude, "stupid" (belog), and wastes energy in merely satisfying his or her personal passions, can, in the Balinese belief system, be reincarnated as an animal-a slug being deemed by some villagers the most lowly of creatures. Indeed, the brain of such a person-otak (the term "thoughts" being deliberately not used as animals do not think)can be compared derogatively to that of an animal. Alternatively, an animal who shows awareness of darma can ascend the status hierarchy and be reincarnated as a human.

All beings, moreover, who strive for liberation, moksa, must first observe the customary rules and obligations of the community. Sutasoma's teachings to the tigress (in Episode 3) are particularly poignant in this context as they vividly relate to the ideals, norms, and values of Balinese society. The tigress is reprimanded for her wickedness in wishing to devour her cubs. Thereby she is neglecting her two roles of parent and spiritual teacher. Furthermore, the cubs will grow up to be cruel and greedy, and will later illtreat their mother, for they know no better. The issue of right behavior between parent and child is one that frequently crops up in drama and life.

\footnotetext{
${ }^{36}$ C. Lévi-Strauss, Totemism (Boston: Beacon Press, 1963), p. 101.

${ }^{37}$ This triad is known as tiga-jnana, but as in the example of the performance, it is rarely referred to by name; only the three forces are mentioned.

${ }^{38}$ See D. Parkin "Introduction" in The Anthropology of Evil, ed. D. Parkin (Oxford: Blackwell, 1985), pp. 1-23, on the predicament of suffering.
} 
Sutasoma also emphasizes that unity should exist between thoughts, speech, and action (see Episode 4), and demonstrates their inter-relationship on the stage in his words and behavior. This triad is often alluded to in the village sphere. While each status group and individual must attain his own point of balance, a person who is upright should not only act in accordance with the customary rules of the community, but also speak in a sweet manner and possess lofty, pure thoughts.

Another important cosmological principle embedded in the prince's teachings is that of ruwa-binèda, the system of complementary opposites (see Episode 4): right/left, young/old, male/female, good/evil (called here kaon). In the play of Sutasoma, for example, the prince represents goodness and the creatures and ogres baseness. Yet both are indispensible to world order. As one Balinese lucidly explained "how can you know evil, if you cannot speak of good" (jèning nènten wènten kaon, nènten meresidayang ngeraos becik).

Ultimately, Sutasoma elucidates to his three pupils that the path of liberation leads an individual to realize a state of non-duality, when the cosmic dichotomies are transcended. It is worth noting here that the elusive, vibrant silhouette of the Kakayonan or Tree of Life, as it fleetingly appears on the screen during the course of any night performance, reiterates this message. As the axis of the world, it symbolically expresses mediation and equilibrium to which continual recourse is taken during the narration. ${ }^{39}$

Dalang I Ewer still expanded on the significance of the prince's teachings and portrayal in this, or for that matter any performance based on the Sutasoma story. To I Ewer, as well as to other dalang, Sutasoma is a prince whose orientation is clearly Buddhist. This manifests itself through his great compassion and gentleness, which is said to arise from his purity. Sutasoma, moreover, follows the path of non-violence and practices asceticism, concentration, and meditation. Thereby he gains control over his volition and senses, and his consciousness is liberated from the limitations of earthly ties. The corollary of this state in the indigenous context is authority and divine radiance 40 which softly emanates from him, referred to as kawibawan (see Episode 1), as well as beauty in Sutasoma's case. Koentjaraningrat in discussing the Javanese idea of power, ${ }^{41}$ uses the same term, pointing out that this quality is conjoined with righteousness, justice, wisdom, and generosity. It is evident that kawibawan is a complex quality in both islands, with deep moral overtones, and is applied to specific persons. In Bali it still may have aesthetic connotations. In demonstrating kawibawan to the other characters in the play, as well as, of course, to the audience watching it, Sutasoma also illustrates his legitimate right to use his authority, or power, for the good of the country.

To the predominantly Sudra audience, who represent the ordinary populace, however, Sutasoma is primarily a wise, benevolent, and just prince and teacher. They rarely link him to the historical Buddha (who in any case many villagers, especially from iso-

${ }^{39} \mathrm{Cf}$. C. Hooykaas, Kama and Kala: Materials for the Study of the Shadow Theatre in Bali, Verhandelingen der Koninklijke Nederlandse Akademie van Wetenshappen 79 (Amsterdam: North-Holland, 1973 ): 33; A. Hobart, Dancing Shadows of Bali: Theatre and Myth (London: Kegan Paul, 1987), pp. 180-81.

40 Some scholarly Balinese use the Sanskrit word téja (spiritual and moral power, fiery energy; Stutley, Dictionary of Hinduism, p. 302) to refer to the king's power and radiance, the emphasis being on the latter attribute. The term, though, is not in common usage with villagers and carries with it a less immediate sense of everyday presence of power and authority than kawibawan.

${ }^{41}$ R. S. Koentjaraningrat, "Javanese Terms for God and Supernatural Beings and the Idea of Power" in Man, Meaning and History, ed. R. Schefold, J. W. Schoorl and J. Tennekes, Verhandelingan van het Koninklijk Instituut voor Taal-, Land- en Volkenkunde 89 (The Hague: Nijhoff, 1980): 133. 
lated hamlets, have not heard of) or an incarnation of him. His enlightened nature, however, distinguishes him from all other wayang heroes, who are actively involved in warfare, which often entails violence and bloodshed. Yudistira from the Mahābhārata is perhaps the closest in character to Sutasoma. Yet he is a rather weak and anaemic figure in Bali, who on Kresna's instigation enters the Great War. Kresna, while conceded to have great authority and mystic power, kesaktian, ${ }^{42}$ is not compassionate and pure like Sutasoma. Kresna is above all a brilliant, devious strategist of war.

It is further interesting that dalang and learned villagers alike may still associate Sutasoma with the idea of the center, syncretic in character, from which light radiates downwards, bringing with it unity and order (see the section on the pictorial arts below, pp. 93-101, where the relevance of this is explored). Lord Buddha in Bali is given the same status as Siwa, who is at the center of fundamental principles of classification, i.e., the five-fold division of the cosmos, panca déwa (five gods) and nine-fold system, nawa sanga. The different gods of the cardinal points are all said to merge into Siwa (or Buddha) who constitutes a higher unity. To a dalang, such as I Ewer, there is no incongruity here. Prince Sutasoma follows the path of Buddha. At the same time, he is an incarnation of Lord Buddha. No other wayang character has such a sublime heritage. Even Kresna is not linked to the sacred center, for he is an incarnation of Wisnu, whose cardinal direction is "to the mountain" (kaja) or north.

This performance of Sutasoma is, of course, a unique event, given to a particular audience. Yet it highlights Sutasoma's spiritual force and nobility, characteristics which are central to the Balinese esteem of the figure. The profundity of the prince's teachings to Gaja Waktra, the tigress, and the serpent also helps account for the frequency with which this scene is portrayed in the other arts.

\section{Contemporary Drama: Derama Gong}

Bali is renowned for its creativity in the performing arts. Yet apart from the shadow theater, only derama gong alludes on occasions to Prince Sutasoma. He is, however, always a minor figure, and hence we will only look briefly at this genre of theater.

According to informants, derama gong began in the village sphere in 1965-1966 after the coup and developed out of the dance-drama jangèr. Thus in its early years derama gong was also called derama jangèr. Jangèr was created in the early twentieth century and has its roots in old village dance customs which no-longer exist. ${ }^{43}$ Like derama gong, jangèr incorporated innovations of new Indonesia and the West.

Derama gong is accompanied by a loud percussion instrument, gamelan gong. Already to villagers its name makes an oblique reference to the period after the coup when strife was rampant. Gong in folk etymology is derived from gonggang to quarrel, to dispute or argue. The stories of this early period, which unfortunately have never been documented, also seem to have reflected the unrest following the coup. They centered on the discontent of the peasants vis-à-vis the high castes, which ended to the

${ }^{42}$ Kings in Bali were often traditionally attributed with mystic power, enabling them to accomplish extraordinary feats, especially in war. Benedict Anderson, "The Idea of Power in Javanese Culture" in Culture and Politics, ed. Claire Holt et al. (Ithaca: Cornell University Press, 1972), pp. 1-69, draws attention to the importance of this concept in Java, where it is called kesakten. Sutasoma too is said to possess mystic power. However, as we have seen in I Ewer's performance, his other qualities emerge as much more significant.

${ }^{43}$ I Madé Bandem and F. E. deBoer, Kaja and Kelod Balinese Dance in Transition (Kuala Lumpur: Oxford University Press, 1981), p. 114. 
detriment of the latter. The legend of Jaya Prana ${ }^{44}$ seems to have been especially popular.

Derama gong until recently was considered an immature dramatic genre, characterized by its experimental nature and progressive tone. Certainly it is still the main theater form that distills issues relating to the modernizing process in Bali, and as such it is often compared to ludruk, the proletarian drama which emerged in the 1930s in the sleazy outskirts of Surabaya. ${ }^{45}$ In the meantime, however, owing to official sponsorship of the arts, its dramatic elements have become more rigid and formal, and this has a bearing, as we will see, on the character of Sutasoma in the plays.

Derama gong, like the masked dance, topèng, and operetta, arja, reaches spectacular levels of display these days. The latter two genres, however, are conceded to have greater aesthetic merit. They are also older and possess a more defined repertoire of traditional motifs and stories. Topèng was first performed in the seventeenth century in Gelgel and arja in the early nineteenth century in Klungkung. ${ }^{46}$ Until relatively recently all these theater genres were sponsored by villages, and they were performed throughout the island, the main occasion being in conjunction with a temple anniversary. They were also given spontaneously in the hamlet council hall. This is still sometimes the case. In the village, derama gong plays attract a large audience, comprising mainly young people of both sexes and middle-aged women. Youngsters point out that they like the lighthearted, often banal stories, that always involve love and romance. Performances also provide an opportunity for flirting which was traditionally frowned on in public.

But increasingly over the last ten years the provincial government and the conservatories have had an influence on the arts. It is through the government that plays of all theater genres are serialized on TV and radio, and this is now the main way that most villagers, especially from isolated hamlets, watch performances. (Another reason why derama gong is less often performed in the village is that tickets have become very expensive, c. Rp.2,000.) During one month in the summer the Arts Center in Denpasar also puts on shows which are attended by the urban elite and wealthy villagers.

Present-day derama gong troupes are made up of about fifteen actors of all castes who come from various districts in Bali (bon-bonan). 47 They require negligible training before going onto the stage where they improvise extensively. This applies especially to the servants who weave piquant sub-plots with the exceedingly flimsy main plot.

The costumes and scenery show Western influence. It is drop-and-wing. The stories have often vague proximity to Panji (Malat) tales. The principal characters in any play are the virtuous prince and princess, their servants, and their so-called "mad" (buduh), ignoble counterparts. A few minor individuals may also enter the plays. Here I want to turn to an actual performance that I witnessed in 1979 in the village of Tegallalang, given spontaneously for the sake of entertainment. Although of mediocre quality, as the

${ }^{44}$ C. Hooykaas, The Lay of Jaya Prana (London: Luzac, 1958).

${ }^{45}$ See J. L. Peacock, Rites of Modernization: Symbolic and Social Aspects of Indonesian Proletarian Drama (Chicago: University of Chicago Press, 1968).

46 Bandem and deBoer, Kaja and Kelod Balinese Dance, p. 53 and p. 90.

${ }^{47}$ Formerly troupes consisted exclusively of actors from one area (koban). Nowadays actors come from different areas, although they have acted often together in a particular troupe. This development has helped lead to the homogenization of the performing arts, for actors spread cultural contact between areas. 
story was disjointed, it is the one time that I witnessed a character called Sang Sutasoma appear on the stage.

The hero of the story is anxiously searching for his beloved who has mysteriously disappeared. Finally, after numerous adventures in the woods he retrieves her. Throughout, the prince is accompanied by his loyal two male servants. Among the individuals whom they encounter is Sutasoma, who is clad simply although his demeanor is dignified. He is surrounded by animals-monkeys, snakes, a tigress, and birds-with whom he seems quietly to be conversing and who are fearlessly following him. A brief interchange occurs between the prince and Sutasoma, in which the prince expresses awe at Sutasoma's love and compassion for wild animals. Throughout the short encounter Sutasoma is distinguished by his straightforward, egalitarian manner of speaking and his simplicity and modesty.

The villagers at that time stressed that Sutasoma and Hanuman were the only two wayang figures that ever entered derama gong stories, although their roles were tangential. Hanuman in wayang is the elevated monkey-god. In derama gong he was essentially a caricature of himself. His appearance can perhaps be explained by the fact that even in the shadow theater he need have no prescribed role, but can enter any story to overcome obstacles. In the same way, he can slip into derama gong where he exhibits a certain comic immediacy in tune with the light-hearted, noisy, and down-to-earth atmosphere of this genre. Sutasoma also appears as a "real" person, no reference being made to his sublime heritage. He is distinguished by his modesty and simplicity and the ease with which he mingles with all classes of humans and animals. In some ways, in the performance given at Tegallalang, Sutasoma epitomized the spirit of equity in the society.

In subsequent years, in the 1980 s, Sutasoma has vanished from the plays. Only allusions are made to him. It can be suggested that his disappearance was due to the increasing influence of the provincial government and the conservatories on, in this case, derama gong. Sutasoma is then a threat and subversive to the bureaucracy in his rejection of materialism and excess. Hence he has to be marginalized.

Official sponsorship of the arts has meant that the dramatic elements of derama gong have been not only refined and formalized, but also to a degree censored. This is illustrated in the following dialogue, recorded in 1987 in Tagallalang, when the servant I Durus compares in glowing terms the ruler of his country with Sutasoma.

I Durus (to Sempol) Our ruler administers the country well. All villages now have schools and education is available to all. Villages also have electricity and water can be fetched from a central tap in the hamlet. Truly, our king is as knowledgeable as Sang Sutasoma from the kakawin who has love and compassion (tresnasih) for all his subjects, including animals.

I Sempol Yes, elder brother, yet there are things which are unsatisfactory, but this will always be the case for both good and bad must exist [on ruwa-binèda, see the shadow theater]. The electricity often breaks down and I have waited in long queues to fetch water! 48

\footnotetext{
${ }^{48}$ This example is taken from an episode of a story which two actors re-enacted at my request in one of their homes in 1987. The actor who played I Durus is renowned for his fluency and wit in the role of the servants in derama gong.
} 
I Durus in his speech draws attention to the modernizing trends evident at the village level. It is of interest to note that I Sempol holds up a slightly disquieting mirror of progress, for he points out that electricity, although now installed in all hamlets, may break down-which happens quite regularly-and central taps are still proving unsatisfactory. I Sempol and his brother, I Durus, are "mad" servants who serve an ignoble king. My informants pointed out that nowadays only "mad" servants are allowed to make critical, albeit delicate, remarks, which allude to procedures introduced by the local government, as reprisals of one sort or another might follow. ${ }^{49}$ The servants of a virtuous master, in contrast, never find fault or grumble about the state of affairs in the country. In the above dialogue their master is even compared to the enlightened Prince Sutasoma of the kakawin.

Derama gong is the theater genre most involved in the process of modernization in Bali. Performances refer to such contemporary issues as the growing traffic on the roads, new technical devices installed in the village, tourism, or the introduction of television sets or films. A mixed Balinese and Indonesian code, too, may be spoken. As the latter has no graded status vocabularies, it helps in certain situations to introduce a greater ease into interaction between members of different castes. These symbols pertain in particular to nationalism, entailing an awareness of the wider world, or in Weber's terms the emergence of "rational" man who justifies his actions by showing that they are traditional. So each performance is a mode of discourse which mediates the dialectic between the symbolic world articulated on the stage and the social relations of the indigenous people in a changing world.

Yet derama gong has changed over the years and concomitantly so has the Balinese experience of Sutasoma in the plays. In the 1970s derama gong was in no sense a highculture art. Its tone was secular and noisy and its dramatic elements fluid, the different sensory codes-visual, auditory, and kinesthetic-being open to interpretation, and even desecration. Hence little regard was paid on the stage to the traditional rules and customs controlling salient relationships in life. I saw this vividly demonstrated in one performance when one of the servants tried to kick the prime minister's head (Plate 3), considered the most sublime part of the body. ${ }^{50}$ Sutasoma at that time could enter plays as a minor prince who was modest and artless and who extended goodwill to all, without discrimination of any kind. In this role he emphasized the democratization in the society, the gradual movement of the common man towards center stage. By the 1980s Sutasoma, however, had virtually disappeared from plays. Due to official sponsorship of the arts, the standard of derama gong was raised by elaborating, stylizing, and formalizing its dramatic elements. In line with this, only allusions are now made to such figures from the Classics as Sutasoma in order to enhance the poetic quality of the plays. At the same time, Sutasoma here represents the morally superior person, a prince of wisdom and benevolence, i.e., a person with whom those in authority wish to identify.

\footnotetext{
${ }^{49} \mathrm{My}$ informants pointed out that the dance-drama which allows the most frequent criticism, although still veiled (meseseret), of the government is sendratari. The presence of dalang on the stage gives the actors a certain immunity in their speeches.

${ }^{50}$ Body symbolism is highly developed in Bali, corresponding to certain conceptions relating to the caste system: the head is associated with the Brahman caste and the other castes with progressively lower parts of the body (see Hobart, Dancing Shadows of Bali, p. 98). Sudras, when addressing high castes, traditionally also lowered themselves bodily on these occasions.
} 


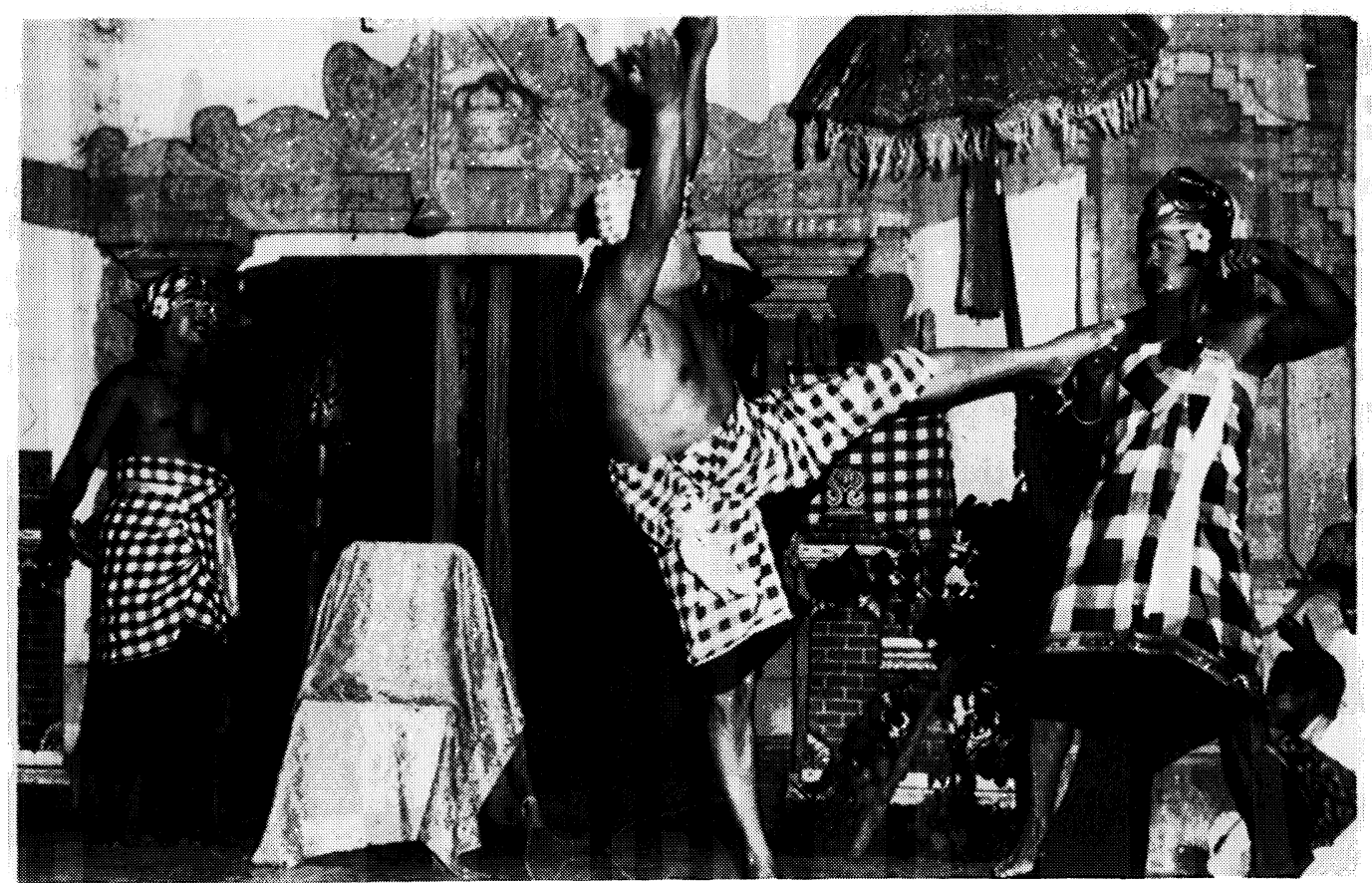

Plate 3. Contemporary drama. The servant tries to kick the head of the prime minister. (1970s)

\section{The Pictorial Arts}

\section{Paintings in Wayang Style}

The earliest series of narrative paintings of the Sutasoma story, among other mythological tales, are on wooden panels lining the ceiling of the seventeenth century pavilion Taman Gili, which is adjacent to the Law Court Kerta Gosa at Klungkung, built at the same time. ${ }^{51}$ While the stylized figures in these polychrome paintings resemble the flat puppets of the shadow theater, their purpose should be related to the rulers who commissioned them.

Kerta Gosa and Taman Gili were built when Bali was still divided into kingdoms, and they should be seen as an architectural unity, expressing core ideas on kingship. Anderson's and Geertz's views on the power politics of Java and Bali are relevant here. Anderson writes that in the Javanese conception "power required a center, syncretic and absorptive in character, and that this center was usually realized in the person of a ruler." 52 Geertz reiterates this idea in the following statement on the state in nineteenth century Bali:

The driving aim of higher politics was to construct a state, by constructing a king. The more consummate the king, the more exemplary the center. The more exemplary the center, the more actual the realm. ${ }^{53}$

\footnotetext{
51 I Gst. Warsika Kertha Gosa at a Glance (Klungkung, 1979), p. 11.

52 Anderson, "The Idea of Power," p. 25.

${ }^{53}$ Clifford Geertz, Negara: the Theatre State in Nineteenth Century Bali (Princeton: Princeton University Press, 1980), p. 124.
} 
The series of narrative paintings of mythological themes in the two pavilions vividly illustrate the poetics of power as conceived of by these scholars. The paintings in both pavilions occupy a particular space on the ceilings, and carry meanings which convey a distinctive conception of the world and the humans in it in relation to both natural and supernatural beings. The architectural scheme of each pavilion is self-centered, and, together with the arrangements of paintings, expresses an ideal order, at the apex of which are gods, kings, and priests. As such it can be suggested that the pavilions seek to exemplify a royal center, a still point in the realm, from which divine favor and knowledge graduated down to the peasants.

The persuasiveness of this socio-cosmic scheme comes initially to the fore at Kerta Gosa where sessions of the Court of Justice were held under the auspices of the Déwa Agung (literally "supreme god") of Klungkung, before its conquest by the Dutch in 1908. The quiet celestial sphere with the gods is at top. This sphere is remote for those sentenced for crimes committed. Further down are sequences of scenes of princely heroes, for the most part derived from the Mahabharata. At the bottom the horrible torments awaiting sinners are depicted.

However, the smaller pavilion Taman Gili, too, gives rise to a static world which professes a total prevailing harmony. The top series of paintings are based on the Sutasoma kakawin. The series begins with the prince leaving the palace to enter the woods in order to meditate. Here he encounters, as in the shadow theater performance, Gaja Waktra, the tigress, and the snake. The tigress tries to maul him, but Sutasoma unperturbed teaches the creatures the way of darma (Plate 4). He then pacifies the demon-king Porusada, and the story ends with him returning, with his wife, to his kingdom.

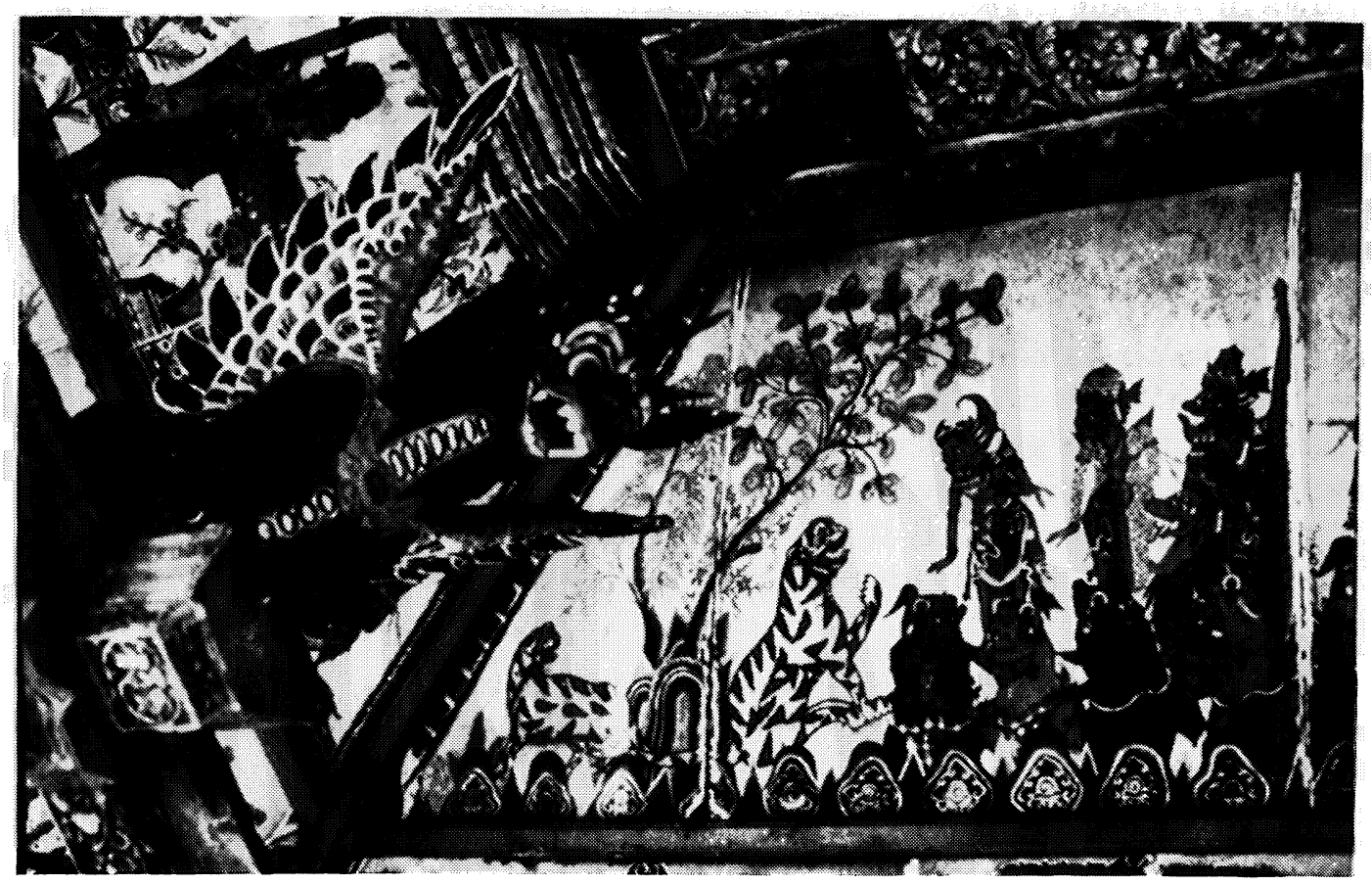

Plate 4. Ceiling painting at Taman Gili. Sutasoma teaching the tigress. The servants squat below. 
Throughout these paintings Sutasoma is characterized by the nobility and tranquility of his bearing and conduct. The series of paintings further down tell the folk tale of Pan Briyut, and at the base the scenes are linked to the Balinese calendrical system.

Taman Gili was used, as was Kerta Gosa, to receive priests and guests, among whom were foreigners, and it is important to realize that the paintings were not just meant to be seen, but that their aesthetic and ethical message was meant to impress the populace. Certainly Sutasoma was an ideal model for the rulers, who conceived of themselves as activators of the divine, to emulate. The prince symbolized authority, justice, and calm beneficence which extended to the most ignorant of his subjects, here represented by the three creatures. The subservient position of the Sudra servants in the paintings who, in contrast to their role in the theater, say nothing, accentuated this message. Moreover, as already mentioned, Sutasoma is the only wayang figure who is associated with the center, i.e., the axis around which the society revolves. It is evident that the paintings in the two pavilions which particularly refer to the Sutasoma story, sang the praises of aristocratic heroes, whereby they glorified and helped legitimize the dynastic power of the rulers.

The ideology of the "theater state," with the king acting as its exemplary center, however, in many ways contradicted reality. As a number of scholars have pointed out, 54 continual intrigue, disputes, and violence existed between and within kingdoms. Moreover, succession to the throne was fraught with strife, dynasties tended to be short lived, and mystic modes of legitimacy were constructed. In short, the repeated upheavals intensified the importance of Kerta Gosa and Taman Gili which, in visual terms at least, presented the veneer of a serene and static socio-cosmological order at the apex of which was the ruler, the Déwa Agung of Klungkung, who became the titular sovereign over the whole island in the nineteenth century.

The following discussion will bring us back to the twentieth century and highlight the volatile changes which allow the Sutasoma story to carry variegated shades of meaning depending on context.

The village of Kamasan, near Klungkung, is still today the center of traditional painting in wayang style. The themes, like those of the paintings at Kerta Gosa and Taman Gili, are predominantly derived from the classical literature, and the figures follow puppet conventions. I Nyoman Mandera is the present teacher of the Kamasan School of Art, which he set up in 1974, and his masterly work of Sutasoma (Plate 5) vividly exemplifies this tradition.

The former place of wayang painting in the society is unclear. It is known, however, that royal courts up to the beginning of the twentieth century acted as patrons of Sudra artists, the so-called sangging. ${ }^{55}$ It was probably also the sangging who painted the ceilings of Kerta Gosa and Taman Gili. The sangging formed hamlets of intermarrying families who covertly guarded their skills. Several such hamlets still exist, one of the most famous being Banjar Sangging in Kamasan, where I Mandera runs his school for largely Sudra boys and girls. It is paid for by the Department of Education and Research.

\footnotetext{
54James Boon, The Anthropological Romance of Bali 1597-1972 (Cambridge: Cambridge University Press, 1977), p. 27; S. J. Tambiah, "A Reformulation of Geertz's Conception of the Theater State" in Culture, Thought and Social Action: An Anthropological Perspective (Cambridge: Harvard University Press, 1985), pp. 316-38.

${ }^{55}$ A. Forge, Balinese Traditional Painting (Sydney: The Australian Museum, 1978), p. 7.
} 


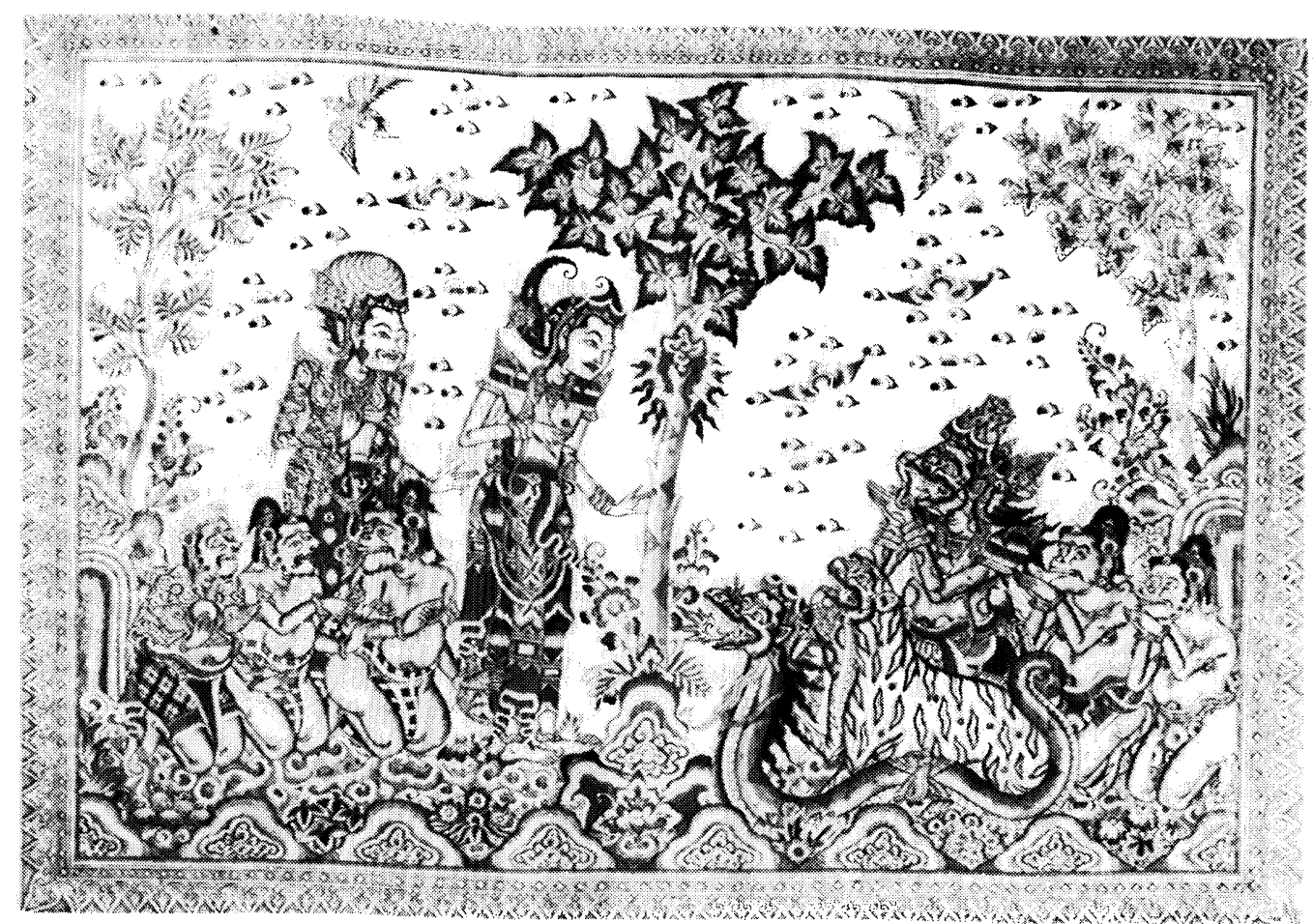

Plate 5. Painting by I Mandera. Sutasoma teaching the snake, tigress, and Gaja Waktra. The servants crouch to either side. (1970s)

In the past, paintings in wayang style were primarily commissioned by royalty or village communities, and the paintings came in two main formats: ider-ider, long narrative paintings, hung under the eaves of pavilions in temples or palaces, and oblong paintings, langsé, used as curtains or wall hangings. Nowadays such paintings are framed, and they have entered the tourist industry, which includes tourists from abroad as well as Indonesians, hotels, and official institutions. Paintings have also been successfully exhibited in Jakarta and the Art Center in Denpasar. I Mandera himself has fulfilled many government commissions. 56

Traditional paintings with mythological themes, such as Sutasoma, seem never to have been portrayed in Sudra houses. Even now, the houses are mostly decorated with calendars of glossy girls, or posters which show President Suharto and refer to government programs. I Mandera is an exception, for paintings in wayang style hang in his modest home.

I Mandera first learned to paint from his mother's brother who was an accomplished artist. As a young boy he practiced by sketching images on the ground with a bamboo stick. Despite the fact that his formal education ended when he was fourteen years old,

\footnotetext{
56 One of his paintings was chosen to hang in UNESCO in Paris to commemorate the Proclamation of Independence and the ousting of the Dutch in 1949. I Mandera pointed out that he chose this painting as it shows the noble giant Kumbakarna, wrongly allied with Rawana, slain in the war. Kumbakarna represents to the artist the devastating struggle against the Dutch in which many Indonesians died. Like Kumbakarna, they were glad to die as they knew that the outcome of the struggle would bring order and peace to their country; greed would be vanquished.
} 
he begins to paint by first reading a contemporary version of the story on which the picture is based, and dwells on its qualitative aspects. His description and interpretation of the painting of Sutasoma poignantly highlight his knowledge and understanding of this particular story. As in most paintings of the Kamasan School a marked duality is built into this picture's composition (Plate 5), reflecting the complementary opposition of wayang plays. A tree on a rock, reminiscent of the Kakayonan, the Tree of Life in the performance, takès the central position. To the left are Prince Sutasoma, the Siwaite priest Kesawa, Tualèn, and Merdah, and a minor servant from the shadow theater called Baru who is included to give the picture balance. To the right are the snake and the tigress, and Gaja Waktra, Dèlem, and Sangut. Again, as in the shadow theater, the servants are the spokesmen of the mythic characters. The prince stands out by the sweetness of his expression, as he inclines gently towards his three pupils. The space around him indicates he is the most important character in the painting.

I Mandera pointed out that the picture's symmetry and pattern gave it clarity and power, whereby a direct aesthetic experience was evoked, enabling both artist and beholder to become responsive to the prince's message. Langer's evocative words come here to mind:

In art, it is the impact of the whole, the immediate revelation of vital import, that acts as the psychological lure to long contemplation. 57

Contemplation in this instance, according to I Mandera, leads to the banishment of the six enemies, sad ripu (lust, greed, anger, disrespect, pride, and envy), which prevent a person from attaining purity, compassion, and wisdom. I Mandera further elucidated that, while these qualities come to the fore in the Buddhist story of Sutasoma, they were also intrinsic to the Hindu-Balinese tradition and any seeker of spiritual awareness would strive to cultivate them.

It is of interest that, apart from its psychological overtones, this painting of Sutasoma, as is the case with many others of the Kamasan School, has additional significance to the artist, which links it to the village sphere and which belies the static, ritualized view of the world expressed by the Balinese nobility in relation to Kerta Gosa and Taman Gili. I Mandera explained that the central tree represents the banyan tree (waringin) which is "cool" (tis). Hamlet councils, renowned for their spirit of equity, are often located near such trees. These impart a "cooling" atmosphere to meetings, ensuring a well-attested outcome to matters negotiated there. In the same way, the tree in the painting provides a fitting setting to Sutasoma's encounter with the three creatures that he seeks to enlighten. As we have seen, the egalitarian spirit that the painting conveys to I Mandera comes to the fore also with derama gong, especially in the 1970s.

\section{Twentieth Century Paintings and Reliefs}

In 1908 the Dutch conquered south Bali, the north having already recognized their suzerainty in 1849. As a result of the establishment of the colonial administration, the power of the indigenous rulers was gradually curtailed. Now the island forms a province in the Unitary Republic of Indonesia. ${ }^{8}$ The former kingdoms have become local administrative centers, kebupatèn, with government councils and political party officials. Each kebupatèn is divided into smaller administrative units, the smallest and

57S. K. Langer, Feeling and Form: A Theory of Art (London: Routledge \& Kegan Paul, 1976), p. 397.

$58 \mathrm{~J}$. L. Swellengrebel, "Introduction" in Bali: Studies in Life, Thought and Ritual, ed. W. F. Wertheim et al. (Dordrecht: Foris Publications, 1984), p. 31. 
most important of which is the hamlet, a partly autonomous community with its own council, already referred to above. In line with these changes, the Balinese nowadays recognize that the center of power, referred to as kekuasaan, radiates out from Jakarta. Kekuasaan is best defined as authority and power, in the sense of possessing the legitimate use of physical force. All my informants stressed that government officials possess no purity or mystic power and rarely wisdom. These qualities are ever increasingly relegated to drama and art.

In view of this, it is noteworthy how many high caste palaces (puri) are adorned with works of art telling of Prince Sutasoma. Other stories which seem popular in palaces are derived from the Mahābhärata, Rām àyana, Arjunawiwāha, and fables, Tantri. With the Balinese penchant for intricate vegetal motifs, scenes are often chosen which take place in luxuriant forests. Diagram 1 lays out the creative works of Sutasoma that I came across. It is of course incomplete. Yet it gives an idea of the distribution of art works of Sutasoma and the main themes depicted. According to I Gusti Ngurah Bagus, the head of the Anthropology Department at Udayana University, other reliefs of Sutasoma exist in Singaraja, Tabanan, and in the hamlet meeting house in Wangayer in Sanur. The last deserve passing notice for they indicate that the Sutasoma story has a wider appeal than just to the nobility.

\begin{tabular}{|c|c|c|c|}
\hline Place & Artist & Material & Date and Theme \\
\hline $\begin{array}{l}\text { Puri Sarèn Kauh } \\
\text { Ubuh }\end{array}$ & $\begin{array}{l}\text { I Lempad, } \\
\text { Bedulu }\end{array}$ & $\begin{array}{l}\text { reliefs of volcanic } \\
\text { stone }\end{array}$ & $\begin{array}{l}\text { c. } 1950 \text { s. Scenes include Sutasoma in } \\
\text { the woods, teaching the animals; } \\
\text { nymphs attempting to seduce him. } \\
\text { (servants included) }\end{array}$ \\
\hline $\begin{array}{l}\text { Puri Sarèn Agung, } \\
\text { Ubud }\end{array}$ & $?$ & $\begin{array}{l}\text { relief volcanic } \\
\text { stone. }\end{array}$ & c. 1983 . Sutasoma teaching animals. \\
\hline $\begin{array}{l}\text { Puri of Déwa Aji } \\
\text { Berata, Batuan }\end{array}$ & $?$ & $\begin{array}{l}\text { carved wood panels } \\
\text { on window. }\end{array}$ & $\begin{array}{l}\text { c. } 1980 \text {. Sutasoma in the woods with } \\
\text { animals. }\end{array}$ \\
\hline $\begin{array}{l}\text { home of I Gusti Ng. } \\
\text { Bagus, Denpasar }\end{array}$ & $\begin{array}{l}\text { Ida Bagus Gegel, } \\
\text { Padangtegal }\end{array}$ & $\begin{array}{l}\text { painting with gold- } \\
\text { leaf. }\end{array}$ & $\begin{array}{l}\text { c. 1930s. Gaja Waktra's fight with } \\
\text { the snake, Sutasoma and a priest in } \\
\text { the background. }\end{array}$ \\
\hline $\begin{array}{l}\text { home of I Lempad, } \\
\text { Ubud }\end{array}$ & I Lempad & $\begin{array}{l}7 \text { ink paintings on } \\
\text { paper. }\end{array}$ & $\begin{array}{l}\text { after } 1935 . \text { Scenes tell of Sutasoma } \\
\text { with the animals, until he } \\
\text { meditates. (servants included) }\end{array}$ \\
\hline $\begin{array}{l}\text { Museum Puri } \\
\text { Lukisan, Ubud }\end{array}$ & $\begin{array}{l}\text { Ida Bagus Buda, } \\
\text { Batuan }\end{array}$ & $\begin{array}{l}\text { ink painting on } \\
\text { paper }\end{array}$ & $\begin{array}{l}\text { 1910. Indra restores Sutasoma to } \\
\text { life. }\end{array}$ \\
\hline $\begin{array}{l}\text { Museum Puri } \\
\text { Lukisan, Ubud }\end{array}$ & $\begin{array}{l}\text { Ida Bagus } \\
\text { Belawa, } \\
\text { Tabasiya }\end{array}$ & canvas and tempera & $\begin{array}{l}\text { 1957. Sutasoma offers himself to } \\
\text { the tigress. }\end{array}$ \\
\hline $\begin{array}{l}\text { Bali Museum, } \\
\text { Denpasar }\end{array}$ & I Lempad & $\begin{array}{l}\text { ink drawing on } \\
\text { paper }\end{array}$ & $\begin{array}{l}\text { after } 1935 \text {. Sutasoma with the } \\
\text { snake. }\end{array}$ \\
\hline
\end{tabular}

Diagram 1. Paintings and Reliefs of Sutasoma 


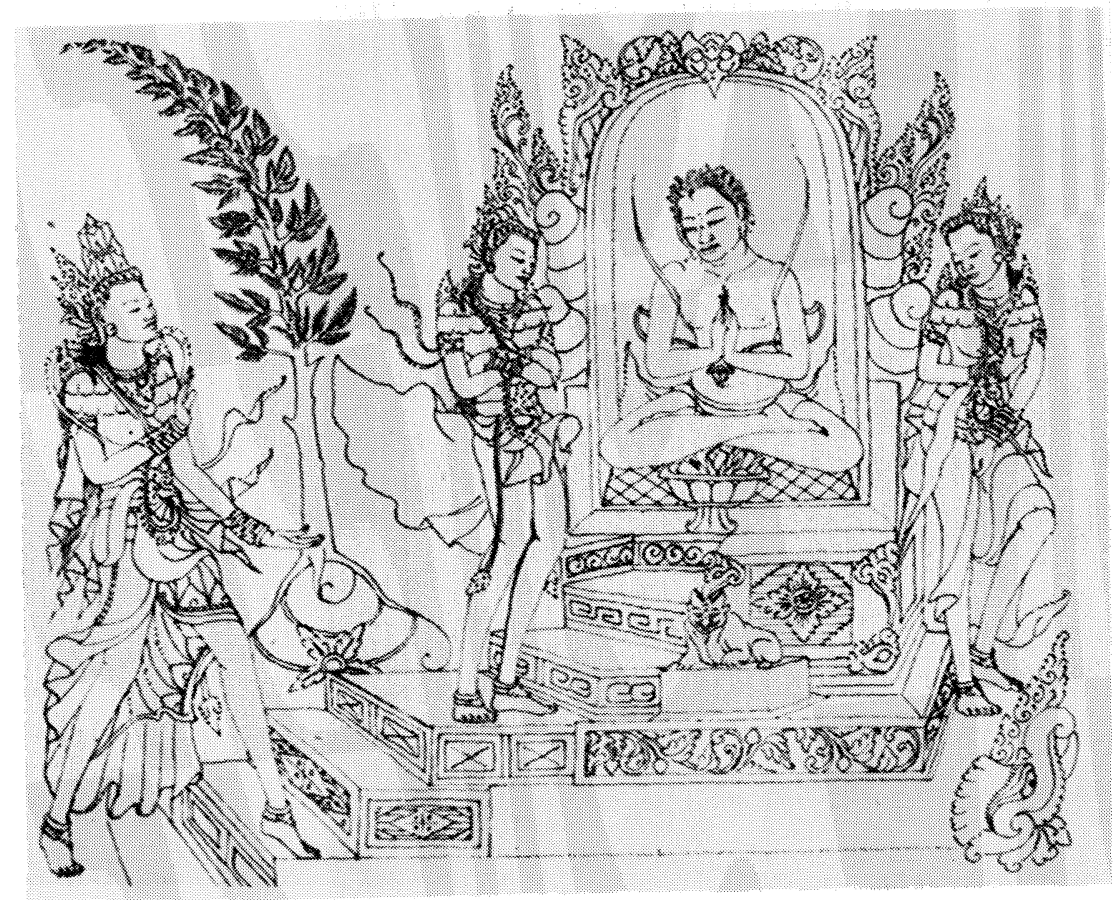

Plate 6. Ink drawing by I Lempad. Sutasoma meditating while celestial nymphs try to tempt him. (after 1935)

Because of the reputation of I Gusti Nyoman Lempad (1862-1978) among Balinese and the originality and vitality of his artistic works, I want to focus on his reliefs in the palaces at Ubud and his delicate ink drawings on paper. Undoubtedly he is one of the most inspired artists in Bali of recent times. I Lempad received no formal literary education and became acquainted with the Classics primarily from watching shadow-theater performances and participating in literary study groups. Seven ink drawings of the Sutasoma story are in the artist's home and an additional one is exhibited in the Bali Museum in Denpasar. They mainly tell of Sutasoma's encounter with the three creatures, his teaching them, and his meditation when he is tempted by beautiful celestial nymphs (Plate 6). While the drawings show signs of Western influence, they are all highly reflective. In his detached serenity while meditating in a cave hermitage, the prince resembles images of Buddha who too was tempted by Mara, the spirit of sensual pleasures. I Lempad's elderly son explained that his father was particularly fond of the Sutasoma kakawin as it was replete with religious and ethical knowledge.

The narrative series of reliefs of soft grey volcanic stone probably also by I Lempad 59 cover an entire wall of one of the pavilions in the Puri Sarèn Kauh in Ubud. Like the ink drawings, they illustrate Sutasoma's sojourn in the woods until he is

${ }^{59}$ The present-day Cokordas of the Puri Sarèn Kauh expressed some discrepancy as to who carved the reliefs of Sutasoma on their puri, palace. One prince pointed out that Cokorda Gede Ngurah, late king of the puri, may have carved them. Alternatively he may have carved them together with I Lempad for they were close friends. Cokorda Gedé Ngurah was also a learned scholar and I Lempad participated in literary study groups held in the puri. 


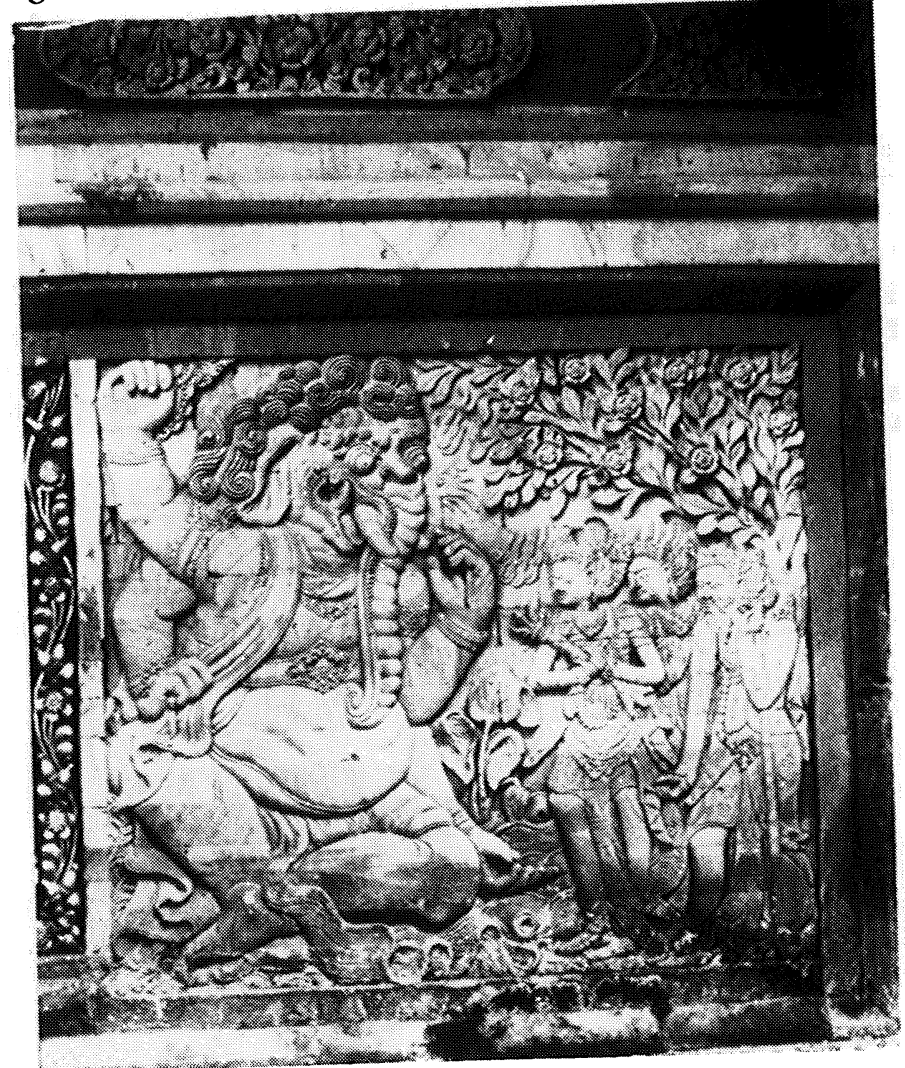

Plate 7. Palace relief. Gaja Waktra towering over Sutasoma and the priests. (c. 1950s)

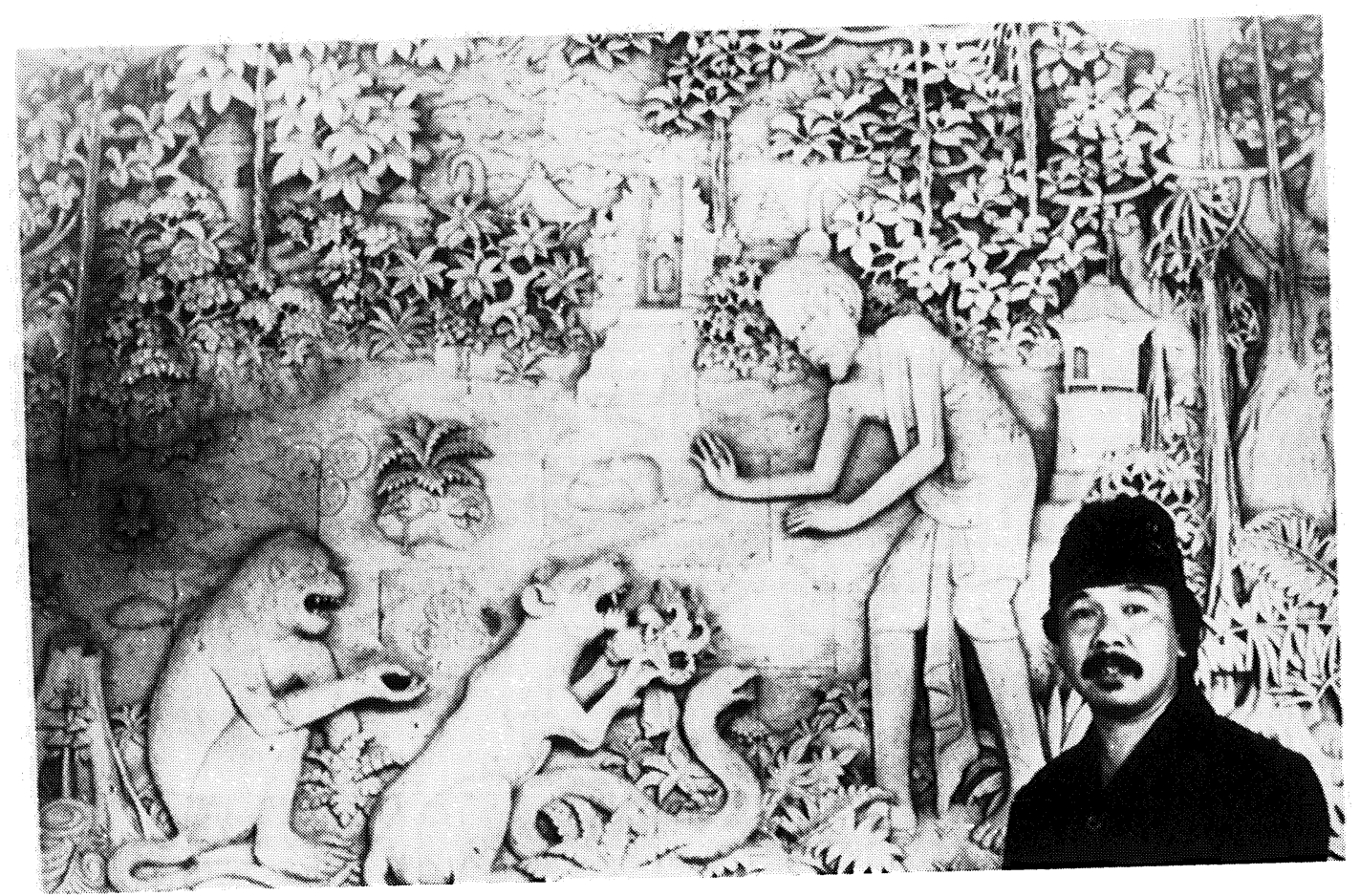

Plate 8. Palace relief. Sutasoma teaching the snake, tigress, and a monkey. Cokorda Gedé Sukawati is standing in front of the relief. (c. 1983) 
received by the priest Sumitra. Throughout the narrative the prince is accompanied by his servants, Tualèn and Merdah. In Plate 7 the huge, portly Gaja Waktra towers over Sutasoma and his two priests, Sumitra and Kesawa.

About four years ago the prince, Cokorda Gedé Sukawati, of the adjacent palace, commissioned (from a sculptor whose name he has forgotten) a further panel of the Sutasoma story (Plate 8). This relief of volcanic rock is on the wall of the sleeping quarters of the elder generation (puri gedong agung), and depicts Sutasoma teaching a snake, a tigress, and a monkey. Apart from its linear quality, characteristic of the wayang style, it is unusually naturalistic and freely conceived. A monkey does not, moreover, occur in the Old Javanese texts. Sutasoma's gaunt frame and attire of a Buddhist priest, padanda Boda, testify to his ascetic life and purity.

These twentieth century artistic creations attest to the continuing popularity of the Sutasoma story in palaces. To the Cokordas Sutasoma is both an eminent prince and a sage, who is Buddhist in orientation as illustrated by his goodness to both humans and creatures of all kinds. It can be suggested that the reliefs were commissioned by the high castes in order to uphold their identity as pure, benign princes who have knowledge of the moral categories, irrespective of their tangible waning of secular and mystic power. The warlike heroes of the Mahäbhärata provide less satisfying ideals these days. This view was expanded on by some Cokordas of the palaces of Ubud. They pointed out that the Sutasoma story fits the twentieth century which has experienced World War II and the bitter revolution in Indonesia against the Dutch, in the wake of the Japanese surrender in 1945. (Interestingly, the abortive coup of 1965 is shrouded in silence and it is rarely brought up.) As Cokorda Suyasa of the Puri Sarèn Kauh explained, goodwill and righteousness have more lasting effects than war which brings only temporary order and peace. Hereby he seems to be alluding again to the calm at the center, a divine unity, from which knowledge and benevolence graduates downward to the peasants.

\section{Conclusion}

In reviewing the significance of the story of Prince Sutasoma in Bali, it is of interest to glance briefly back to India where the story originated. It is striking that Buddha in his teachings emphasized the two qualities, wisdom and compassion, which he saw as inseparably linked; a person seeking insight must develop both equally. ${ }^{60}$ These qualities are epitomized by Sutasoma, irrespective of the transformations that the story underwent, from Mpu Tantular's kakawin to its various manifestations in Bali. But here, the story was assimilated into markedly syncretic Balinese traditions. Moreover, as has emerged from the above discussion, the people's experience of the story differs according to context and the modes of perception of those involved.

On the one hand, Sutasoma glorifies and helps to legitimize the status of the high castes. This is persuasively illustrated by the series of painted panels of the Sutasoma story on the ceiling of Taman Gili, the adjacent pavilion to the seventeenth century Law Court, Kerta Gosa, of the supreme king, Déwa Agung, of Klungkung. The kings, especially at that time, may have sought to exemplify a royal center, the axis of the world, from which divine favor graduated downward to the peasants. Sutasoma is an excellent vehicle for this, being often considered in Bali an incarnation of the central god of the different cosmological systems. Hence the prince is an ideal figure for the ruler to emu-

${ }^{60}$ W. Rahula, What the Buddha Taught (London: Gordon Fraser, 1982), p. 46. 
late in order to affirm publicly his claim to divine authority and power, in the Balinese and Javanese sense, entailing knowledge, righteousness, justice, and generosity, and, in relation to Sutasoma, beauty and purity. High castes, such as the Cokordas in Ubud, even today may allude to this still center in discussing the meaning of the story, irrespective of changing times.

In contemporary drama, derama gong, on the other hand, especially in the 1970s, Sutasoma appeared as a simple, artless, and modest prince who extended goodwill to all humans and animals. In a sense, he represented here the spirit of equity in the society. However, in subsequent years, he virtually disappeared from plays. It seems likely that he was perceived as a threat by the emerging petty bourgeoisie and urban elite, who ever increasingly had an influence on the arts and who strove to attain wealth and the trappings of refinement in order to legitimate their authority to the populace. Hence the prince had to be marginalized.

It is of interest that it is primarily the intelligentsia, among whom dalang, skilled craftsmen, and artists belong, who experience Sutasoma as an enlightened prince, from whom divine radiance emanates, and who follows an essentially Buddhist path. Many of them are acquainted with classical literature, often having gained this knowledge by participating in literary study groups or from the shadow theater.

The shadow theater is in fact probably the most important medium for perpetuating and disseminating the Classics, to which the Sutasoma story belongs. To the predominantly Sudra audience Sutasoma is rarely linked to Buddha. In a play, such as the one given by dalang I Ewer, however, the prince is distinguished from all other wayang heroes, by his wise and compassionate nature, his gentle and dignified demeanor, and his sweet eloquence as he speaks to others.

The audience of a shadow-theater performance can identify with particular ease with the Sudra servants on the stage, who reflect the Balinese world and who frolic and clown around, bringing the stories to life through their translations, commentaries, and explanations. While such dichotomies as intellect versus emotions, reality versus fantasy, superior versus inferior, reverberate below the surface of the plays, this level does not concern the spectators. What stimulate them are the ideals, values, feelings, and beliefs that mesh in an intricate kaleidoscope on the stage and are orchestrated in terms familiar to them. Through this discourse, resolution of human existential predicaments is sought and an attempt is made to understand what is morally virtuous or, in contrast, impure and wild, which ultimately negates happiness and civilized life. A play based on the Sutasoma story is unusual for this genre of theater as the prince subdues those who are still "stupid" and uncouth (represented here by the elephant-headed giant Gaja Waktra, the tigress, and the snake) not by warfare, but through his spiritual force.

So the Sutasoma story continues to be articulated through different expressive genres in Bali-theater, reliefs, paintings, and literary study groups-its varying significance relating to the people involved. However, it must be remembered that each performance is ephemeral. In each the story of the noble prince Sutasoma taming the wilderness is revitalized, renegotiated, and recreated for the benefit of a particular audience. In the same way, each artistic or poetic work, while it must arise out of the tradition, is dynamic and unique. This highlights the fact that everything in the world is relative, conditioned, and impermanent. 